\title{
Highlights
}

\section{A natural gas hydrate system on the Exmouth Plateau (NW Shelf of Australia) sourced by thermogenic hydrocarbon leakage}

Matteo Paganoni ${ }^{a^{*}}$, James J. King ${ }^{\text {a }}$, Martino Foschi ${ }^{\text {a }}$, Katy Mellor-Jones ${ }^{\text {a }}$, and Joe A. Cartwright $^{\mathrm{a}}$

a Department of Earth Sciences, University of Oxford, South Parks Road, Oxford OX1 3AN, UK.

*now at Shell Global Solutions Intenational, B.V., Rijswijk, Netherlands.

Corresponding author: Matteo Paganoni (matte89paga@gmail.com)

\section{HIGHLIGHTS}

- A natural gas hydrate system is interpreted to occur on the Exmouth Plateau

- The hydrocarbon plumbing system is controlled by deep tectonic structures

- Both cross-stratal and stratal pathways supply gas to the hydrate stability zone

- The origin of the hydrate-forming gas is interpreted to be thermogenic

- The gas hydrate reservoir is composed of nannofossil and foraminifera-rich oozes 


\title{
A natural gas hydrate system on the Exmouth Plateau (NW Shelf of Australia) sourced by thermogenic hydrocarbon leakage
}

\author{
Matteo Paganoni ${ }^{a^{*}}$, James J. King ${ }^{\text {a }}$ Martino Foschi ${ }^{\text {a }}$ Katy Mellor-Jones ${ }^{\text {a }}$ and Joe A. \\ Cartwright $^{\mathrm{a}}$ \\ ${ }^{\mathrm{a}}$ Department of Earth Sciences, University of Oxford, South Parks Road, Oxford OX1 3AN, UK. \\ *now at Shell Global Solutions Intenational, B.V., Rijswijk, Netherlands. \\ Corresponding author: Matteo Paganoni (matte89paga@gmail.com)
}

\begin{abstract}
The identification of natural gas hydrates and shallow free gas in sedimentary basins is critical for understanding the organic carbon cycle dynamics in the shallow geosphere, as well as for geohazard studies related to the development of commercial hydrocarbon fields. In this study, we report for the first time the evidence for the potential occurrence of a natural gas hydrate system along the continental margin of Australia, on the Exmouth Plateau (NW Shelf). By the use of high-quality 3D seismic data, calibrated by downhole data from ODP and industry boreholes, we interpret a series of shallow high-amplitude anomalies, including patchy bottom-simulating reflections, as the seismic expression of localised accumulations of free gas beneath the base of hydrate stability, and overlying high-saturation hydrates or authigenic carbonates. The hydrate-bearing reservoir is constituted by Neogene and Quaternary fine-grained carbonate nannofossil and foraminifera-rich oozes. The patchy distribution of the shallow free gas and hydrate accumulations, which reflects the geometry of deeper fault blocks, is hypothesised to result from the leakage of thermogenic gas from deeper reservoirs. The interpretation of a thermogenic origin for the hydrate-forming gases is supported by (1) the existence in the study area of several thermogenic gas discoveries within Late Triassic reservoirs, (2) seismic evidence of cross-stratal and stratal pathways for migrating gases in the overburden, (3) the presence of free gas accumulations at depths intermediate between the deep reservoirs and shallow gas hydrate systems, and (4) geochemical and lithological evidence that the conditions which favour the generation of shallow microbial gas are not present in the area. The acquisition of downhole log and sample data through the observed seismic amplitude anomalies is necessary to test the interpretations and hypotheses presented in this manuscript.
\end{abstract}

Keywords: gas hydrates; free gas; thermogenic gas; gas reservoir; bottom-simulating reflection; amplitude anomalies; fluid flow. 


\section{Introduction}

Natural gas hydrates and shallow free gas are critical components of hydrocarbon plumbing systems and organic carbon cycle dynamics in a variety of sedimentary basins (Baba and Yamada, 2004; Borowski, 2004; Tréhu et al., 2006; Collett et al., 2009; Bünz et al., 2012). Methane-rich hydrate-forming gases are supplied through a variety of processes, including short and long-range diffusion, and advective migration mechanisms, where the source gas is of microbial, mixed or thermogenic origin (Sassen et al., 1999; Milkov, 2005; Malinverno and Goldberg, 2015).

The bottom-simulating reflection (BSR) is a typical reflection seismic proxy of such systems and is often assumed to approximate the base of the gas hydrate stability zone (BGHSZ) (Holbrook et al., 1996). The lateral continuity of BSRs varies as a function of the availability of methane in the system, lithology, free gas distribution, and seismic acquisition parameters (Shedd et al., 2012; Hillman et al., 2017). Regardless of the seismic expression of BSRs, it is well agreed that even small amounts of free gas in the sediment pore space are enough to change the acoustic character of shallow sediments dramatically and, therefore, generate high amplitude anomalies (Lee, 2004). In contrast, natural gas hydrates are only seismically visible if they occur at elevated concentrations along permeable layers or within pockmark and chimney-like features (Boswell et al., 2016; Fuji et al., 2015; Matsumoto et al., 2017; Marsset et al., 2018).

The characterisation of cross-stratal pathways for hydrocarbon migration is critical for understanding long-range advective systems fostering hydrate accumulation. Such pathways can include different type of faults, as well as chimney-like features (Gorman et al., 2002; Hustoft et al., 2007; Crutchley et al., 2013; Simonetti et al., 2013; Li et al., 2017). Identifying these cross-stratal components of hydrocarbon plumbing systems is also part of the seal risk assessment for deepseated conventional hydrocarbon traps (Wiprut and Zoback, 2000; Gartrell et al., 2004; Bailey et al., 2006; Cartwright et al., 2007; Løseth et al., 2009; Hermanrud et al., 2014). Overall, the quality of a seal depends on its geometry, capacity, and integrity, with the retention of hydrocarbon fluids 
at depths being potentially compromised by seal fracturing, faulting, erosion, or lateral changes in the seal thickness and physical properties (Downey, 1984; Watts, 1987; Jones and Hillis, 2003; Underschultz, 2007). Upon seal failure, hydrocarbon fluxes from deep-seated reservoirs migrate towards the shallow portions of the overburden, the water column, and the atmosphere, actively contributing to the dynamics of the organic carbon cycle (Judd and Hovland, 2007; Etiope et al., $2008 \mathrm{a}$ and $b)$.

The NW Shelf of Australia (or Westralian Superbasin) is a $\sim 800,000 \mathrm{~km}^{2}$ wide passive margin, whose regional state of stress is affected by a complex system of tectonic forces (Hillis et al., 2008). This area is widely investigated for conventional oil and gas exploration (Longley et al., 2002) and likely contains the vast majority of the conventional hydrocarbon resources of the country (Leather et al., 2013). Within this region, the presence of seal-bypass systems (cf. Cartwright et al., 2007) is well-documented, and shallow seismic amplitude anomalies indicative of hydrocarbon migration have been previously observed (Hovland et al., 1994; Cowley and O'Brien, 2000; Gartrell et al., 2004). The occurrence of natural gas hydrate systems (NGHSs, see Collett et al., 2009) along the continental margin of Australia has never been reported, although the past presence of gas hydrates has been inferred by Imbert and Ho (2012), from the observation of collapse features (Barrow sub-Basin, Northern Carnarvon Basin), interpreted as fossil hydraterelated pockmarks (dated Paleocene to Eocene).

In this study, we present seismic evidence for the potential presence of an NGHS in the NW Shelf of Australia, specifically in the region of the Exmouth Plateau, in the Northern Carnarvon Basin (Exon et al., 1992; Boyd et al., 1993) (Fig. 1A). The seismic expression of such system is inferred to reflect the impact of free gas, hydrates and potentially authigenic minerals on the seismic reflection amplitude. In this region, characterised by sediment starvation over the entire Tertiary and Quaternary (Boyd et al., 1993; Tindale et al., 1998), several deeply-rooted hydrocarbon 
83 accumulations and fault-controlled seepage patterns are suggested to play a critical role in 1 84 controlling the development of shallow hydrate and free gas accumulations. 


\section{Geological setting}

\subsection{TECTONO-STRATIGRAPHIC EVOLUTION}

The NW Shelf of Australia has experienced a complex tectonostratigraphic history, which started with the Gondwana break-up, and is followed by several extensional events, which ultimately led to the formation of a vast passive margin, influenced in the North by a NE-SW farfield compression (Exon et al., 1992; Gartrell, 2000; Hillis et al., 2008). The Exmouth Plateau is an extensive ( $600 \mathrm{~km}$ long and 300-400 km wide) marginal plateau, which is separated from the NW Shelf of Australia by the Exmouth, Barrow, and Dampier sub-basins to the SE and E, whereas its SW, NW, and NE margins are limited by three Mesozoic abyssal plains (named Cuvier, Gascoyne and Argo). The plateau consists of a $\sim 20 \mathrm{~km}$-thick continental crust block, which was subject over the Phanerozoic to various tectonic events, including a Permo-Carboniferous failed rifting event, followed by intracratonic sag subsidence, tectonic stretching, rifting, and continental passive margin subsidence (Exon et al., 1992; Karner and Driscoll, 1999; Eyles et al., 2003).

The Late Paleozoic and Triassic deposits (Locker Shale and Mungaroo Formation (Fm.)) unconformably overlie older sediments and record a long-living period of intracratonic fluviodeltaic to shallow marine sedimentation (Exon and Buffler, 1992a and b). The thickness of these Paleozoic and Triassic deposits is by far larger than that of the more recent Jurassic to present day stratigraphy. The marine transgression culminated in the Rhaetian with the deposition of the thin, shallow marine Brigadier Fm. Different phases of tectonic extension characterised the period spanning from the Late Triassic to the Early Cretaceous (Gartrell et al., 2016). A first rifting event, which failed to produce a proper break-up and ended in the Callovian/Oxfordian, is expressed by prominent normal faulting, uplift, and erosion of the Triassic sediments. This extensional event ultimately caused differential subsidence and the deposition of Mid Jurassic shallow marine marly/clayey sediments (Athol Fm. and Murat Siltstone), and Late Jurassic restricted shelf finegrained organic-rich sediments (Dingo Claystone), which are either absent or condensed along the 
Exmouth Plateau (particularly on the structural highs), but well-expressed in the nearby BarrowDampier Sub-basin/Kangaroo Trough (Volkman et al., 1983; Exon and Buffler, 1992; Haq et al., 1992).

The second extensional event (Callovian/Oxfordian-Tithonian) was characterised by fault reactivation during the deposition of the Dingo Claystone, under open marine anoxic conditions. The onset of the extension in the Berriasian within the Gascoyne and Cuvier rifts was followed by the deposition of a thick clastic wedge (i.e. the Barrow Group) across a subsiding Exmouth Plateau, owing to a prominent rift-shoulder uplift occurring in the SE (Exon et al., 1992; Boyd et al., 1993; Black et al., 2017). Break-up along the Gascoyne and Cuvier rifts (Hauterivian) also coincided with the termination of a clastic source from the continent, and by the subsequent deposition, above the break-up unconformity, of transgressive marine claystones (Muderong Shale), deepwater radiolarites, (Windalia Radiolarite) (Hauterivian-Aptian), and hemipelagic calcareous claystones, equivalent to the Gearle Siltstone (Albian-Cenomanian/Coniacian?). The deposition of these sediments was coeval with a sea-level rise, related to thermal reequilibration of the lithosphere (post break-up thermal subsidence) and tectonic-related climate changes (Exon and Buffler, 1992; Haq et al., 1992; Karner and Driscoll, 1999) .

The Late Cretaceous was dominated by the deposition of marly chalks and nannofossil chalks (equivalent to the Toolonga Calcilutite and Miria Marl/Withnell Fm.), which mark the onset of passive margin depositional conditions with deepwater carbonate sedimentation (Haq et al., 1992; Black et al., 2017). This trend, characterised by the deposition of nannofossil and foraminifera-rich chalks and oozes (equivalent to the Cape Range Group to Dockrell Fm. and Delambre Fm.), continued throughout the Cenozoic, up to present-day, with a major hiatus in the Middle Miocene (Haq et al., 1990; Exon et al., 1992; Haq et al., 1992). From the Middle Miocene, the influence of far-field tectonic stresses is further considered to have caused fault reactivation, inversion, and folding along the margin (Hillis et al., 2008; Müller et al., 2012). At present, the stress field in the 
area of the Exmouth Plateau is interpreted to range from normal to strike-slip, with an approximately E-W maximum horizontal stress in the latter scenario (Bailey et al., 2016b, a).

\subsection{PETROLEUM SYSTEM AND EVIDENCE OF HYDROCARBON SEEPAGE}

The petroleum system of the Exmouth Plateau is characterised by a dominant gas-prone typeIII coaly Triassic source rock, within the Mungaroo Fm, and possible subsidiary gas-prone source rocks of Lower Jurassic and Early Triassic Locker Shale (Cook et al., 1985; Geoscience Australia, 2012, 2014; Chongzhi et al., 2013). The Upper Jurassic shales and Early Cretaceous siltstones are considered too immature to generate thermogenic hydrocarbons in this area, and the significant amounts of methane-dominated gases dissolved in the pore-waters and detected during ODP Expedition 122 (Sites 762 and 763) are interpreted to be mainly sourced by deeper and mature Triassic or older type-III source rocks (Snowdon and Meyers, 1992).

Along the Exmouth Plateau, the major reservoirs are represented by sand-prone facies of the Triassic Mungaroo Fm. and the Early Cretaceous Barrow Group, with further potential reservoirs present in Upper Triassic carbonate build-ups (Exon and Willcox, 1980; Chongzhi et al., 2013; Geoscience Australia, 2014; Velayatham et al., 2018). The Muderong Shale constitutes the regional top seal of the study area, although intra-formational and local seals are recognised at the top of the Mungaroo Fm. (transgressive clay-rich sediments), in the Brigadier Fm., and the shale-rich Late Triassic and Jurassic sediments (Exon and Willcox, 1980; Chongzhi et al., 2013; Geoscience Australia, 2014).

Cowley and O'Brien (2000) and Jablonski et al. (2013) reported the occurrence of different trap styles in the region of the Exmouth Plateau, including tilted fault-blocks with upper Triassic gas reservoirs (e.g. the Jupiter, Eendracht, Brederode and Thebe gas discoveries), and gentle anticline-shaped structures (e.g. the Scarborough gas discovery) (Geoscience Australia, 2012, 2014), thought to have formed as a response to both Mesozoic rifting events and the Neogene to 
present-day tectonic deformation (Hillis et al., 2008; Hengesh et al., 2011; Jablonski et al., 2013; Williams, 2018). Evidence of hydrocarbon seepage (or leakage) from deep reservoirs up to the shallow subsurface is widely reported along the NW Shelf, including the region of the Exmouth Plateau (e.g. Jupiter and Scarborough structures, see Cowley and O'Brien, 2000; Jablonski et al., 2013).

\section{Methods}

We used the Petrel E \& P Software Platform to interpret a post-stack 3D seismic survey, named Bonaventure, acquired by WesternGeco (commissioned by Chevron Australia Pty Ltd) in a time-migrated converted format. The $3 \mathrm{D}$ seismic data is processed to $0^{\circ}$ phase $(\mathrm{N}$. American polarity), with inline ( $\sim \mathrm{E}-\mathrm{W})$ and crossline $(\sim \mathrm{N}-\mathrm{S})$ spacing of 18.75 and $12.50 \mathrm{~m}$, respectively, $4 \mathrm{~ms}$ vertical sample interval, and covers an area of $4144 \mathrm{~km}^{2}$ (Fig. 1). Considering an interval velocity of $\sim 1700 \mathrm{~m} / \mathrm{s}$ for the first $\sim 200-300 \mathrm{~ms}$ TWT of overburden, in line with existing well-to-seismic ties (e.g. Haq et al., 1990; Chevron Australia Pty Ltd, 2011b), and a 45-50 Hz dominant frequency, we obtain a maximum vertical separable resolution of $\sim 8-10 \mathrm{~m}$. The lateral resolution ranges between $\sim 12.50$ and $\sim 40 \mathrm{~m}$, taken as intermediate between the bin spacing and the dominant wavelength (Cartwright and Huuse, 2005). The seismic data has been stratigraphically calibrated with results from ODP drilling (Leg 122, Site 762), which took advantage of pre-existent industrial borehole information (Haq et al., 1992; Boyd et al., 1993), as well as with well-to-seismic ties in completion reports of the wells Eendrach-1, Brederode-1, Arnhem-1, Kentish-Knock-1, Guardian-1 (a sidetrack well from Kentish Knock-1), Kentish-Knock South-1, and Thebe-1 (Esso Australia Ltd, 1981b; BHP Billiton Petroleum Pty Ltd, 2008; Chevron Australia Pty Ltd, 2010b, c, 2013b, 2014). These wells were drilled within the area covered by the Bonaventure survey, with Thebe-1 located immediately outside its NE margin (Fig. 1B). 
We interpreted the seismic data with the primary aim of detecting amplitude anomalies potentially indicative of the presence of NGHSs (cf. Boswell et al., 2016) in the Late Paleogene to the present day stratigraphy, where conditions for gas hydrate stability are present and could influence the hydrocarbon plumbing system. These anomalies include enhanced reflections with polarity both opposite (soft reflections) and equal (hard reflections) to that of the seafloor, where such anomalous reflections are considered to indicate, respectively, a decrease and an increase in the acoustic impedance. In NGHSs, enhanced soft reflections may indicate shallow accumulations of free gas, while enhanced hard reflections may indicate hydrate-bearing sediments at elevated concentrations, as well as methanogenic carbonates (Paull et al., 2008b; Boswell et al., 2016). Other typical elements of NGHSs include hydrate pingoes and hydrate-related pockmarks, which represent, respectively, the positive and negative bathymetric expressions of areas of concentrated hydrate accumulation and gas-rich fluid fluxes (Serié et al., 2012; Riboulot et al., 2016).

The seismic interpretation was assisted by the computation of theoretical 'bulk conditions' BGHSZ surfaces that were integrated within the 3D seismic cube. These BGHSZ surfaces were calculated using the CSMHyd software (Sloan Jr and Koh, 2007), for different geothermal gradients, a seafloor temperature of $5^{\circ} \mathrm{C}$, a porewater salinity of 3.55\% (De Carlo, 1992; Swift et al., 1992), and a gas composition consisting of pure methane. The depths of the BGHSZ were incorporated into the time-migrated seismic data by applying a velocity of $1700 \mathrm{~m} / \mathrm{s}$.

To relate the occurrence of gas hydrates and shallow free gas to the whole hydrocarbon plumbing system, we mapped the lateral extent of deep direct hydrocarbon indicators (DHIs) present in the Mesozoic stratigraphic intervals (mostly in the Upper Triassic Mungaroo Fm.). The observed DHIs include enhanced soft reflections conformable to structure, and flat spots (i.e. hydrocarbon-water contacts). These DHIs are confidently interpreted as deep thermogenic gas accumulations, on the basis of drilling results (BHP Billiton Petroleum Pty Ltd, 2008; Chevron Australia Pty Ltd, 2010b, c, 2011b, 2013b, 2014). These observations have been integrated with the 
6

seismic detection of potential fluid-flow pathways such as gas chimneys and faults (cf. Løseth et al., 2009; Andresen, 2012; Jablonski et al., 2013). Given that the study area is characterised by pervasive rift-related normal faults (Exon et al., 1992), we image their distribution and evaluate their role in impacting hydrocarbon migration, by generating seismic attribute maps of key stratigraphic horizons and measuring their dominant strike (see https://www.seismar.net/downloads/ for more information on the code used to extrapolate the fault strikes). We also use seismic attributes to image a widespread polygonal fault system (Cartwright and Lonergan, 1996; Cartwright and Dewhurst, 1998).

An additional element evaluated in this study was the total TWT vertical thickness of the interpreted sealing units for the hydrocarbon reservoirs trapped in the Upper Triassic sediments. Thus, we generated a TWT isochore map for the interval separating the top of the Muderong Shale (regional seal) from the top of the Mungaroo Fm. To this end, we further examined each shallow anomaly and deep DHI with respect to the nature of the sealing units (top and fault seals), the presence of erosion on the footwall blocks, and lack of deposition of sealing units.

Finally, a suite of temperature and geochemical data was used to constrain the controlling factors on the stability and occurrence of gas hydrates. This data includes (1) ODP (Leg 122, Sites 762 and 763) and industry borehole temperature measurements, (2) at ODP Site 762, geochemical information on porewater sulphate and chloride contents, the amount of carbonate and total organic carbon (TOC) in the sediment, and headspace methane gas concentrations (see Haq et al., 1990; De Carlo, 1992; Snowdon and Meyers, 1992), and (3) the molecular and isotopic compositions of reservoir gas samples recovered in different commercial boreholes in the study area (see BHP Billiton Petroleum Pty Ltd, 2008; Chevron Australia Pty Ltd, 2010b, c, 2011b, 2013b, 2014). 


\section{Observations and Interpretations}

\subsection{MAIN GEOLOGICAL AND STRUCTURAL ELEMENTS OF THE STUDY AREA}

The Bonaventure 3D survey covers an area located immediately west of the Exmouth Plateau Arch (Scarselli et al., 2013; Bailey et al., 2016b). Following the stratigraphic calibration provided by industry and ODP boreholes in the study area, nine seismic units have been defined (Figs. 2, 3). The main structural features observed in seismic sections are represented by NNE-SSW to N-S trending normal faults, formed during the early stages Mesozoic rifting and imaged in the TWT and variance extractions of the top Mungaroo Fm.-base Brigadier Fm. (i.e. top of Unit 1-base of Unit 2) (Figs. 3, 4). The most prominent of these faults are characterised by hundreds of milliseconds (ms) TWT of displacement, and considerable curvature, as well as variations of throw along strike. We observed that the most significant throw variations and strike curvature are focused in the presence of oblique fault linkage zones and relay ramps, which are interpreted to act as stress and strain transfer zones (Fig. 4A) (Fossen and Rotevatn, 2016). Thirteen footwall blocks show evidence of erosion, in the form of fault scarps, which principally impacts the uppermost portions of the Mungaroo Fm. (Unit 1) and Brigadier Fm. (Unit 2) (Figs 3, 4B).

The Jurassic sediments (Unit 3) are seismically reflective but spatially discontinuous across the study area. This stratigraphic interval is in fact extremely thin to absent at the footwall crests of the fault blocks and reaches its maximum thickness in the hanging-wall depocentres (Fig. 3). The Barrow Group (Unit 4) is a westward-dipping seismically blank wedge, exhibiting a thickness reduction in the same direction, but with a three-dimensional geometry which is impacted by the underlying structural highs and lows, and by internal faulting in the SE portion of the study area. The overlying Aptian to Cenomanian interval (Muderong Shale, Windalia Radiolarite, and Lower Gearle Siltstone equivalents, i.e. Units 5-6, see Fig. 5A, B), is instead relatively continuous, in terms of overall thickness and seismic character. However, a possible combination of differential compaction and fault reactivation resulted in the inheritance of the main structural trends defined by 
the underlying fault blocks. Evidence of differential compaction and possible tectonic fault reactivation is visible throughout the entire Late Triassic-Cretaceous section, although with less significant displacements than in the older stratigraphy (Fig. 3).

The geometry of the Late Cretaceous to Mid Miocene reflections (Units 7-8) is still impacted by the underlying rift-related structures. Across this interval, the reflections are polygonally faulted in many sectors of the study area (Fig. 3). The polygonal fault pattern is nicely shown by the blended TWT-variance map of the Top Maastrichtian horizon (top Unit 7-base Unit 8) and by an intra-Palaeocene reflector named 'P' (Fig. 5C, D). Where the impact of underlying structures on the reflection geometry is less pronounced, the fault strike directions are oriented in two preferential perpendicular directions ( NNE-SSW and WNW-ESE, Fig. 5C, D). The reflections interpreted to indicate Oligocene to Mid-Miocene sediments locally display mounded and moat-like geometries (Fig. 3), suggesting the impact of bottom currents on the depositional architecture (cf. Rebesco et al., 2014).

The stratigraphy comprised between the Mid-Miocene unconformity and the seafloor is characterised by relatively flat reflections, conformable over the majority of the study area, with some exceptions, where mass-transport deposits (MTDs) and erosion have impacted stratigraphic continuity (e.g. Fig. 3C, see also Scarselli et al., 2013). The interpreted Mid-Miocene unconformity, in the northeastern sector of the survey, represents the regional upper tier boundary of the polygonally faulted interval (Fig. 3). This surface mimics the underlying tectonic features, especially in the NW sector of the study area (Fig. 5E). However, from the Mid-Miocene upwards, the reflections have an overall dip direction towards the $\mathrm{NW}$, in line with that of the present seafloor. The seafloor is further characterised by clear evidence of slope instability, in the form of steep headscarps and SE-NW trending flow corridors, expressions of MTDs that have been identified within the Oligocene to present day succession (e.g. the Bonaventure complexes, see Scarselli et al., 2013) (Fig. 1B). The margins of the flow corridors are punctuated by circular 
depressions (Fig. 1B), which do not appear to relate to deep tectonic features or seismic anomalies indicative of cross-stratal fluid pathways and could be the product of gravity/load instabilities induced by the most recent debris flows.

\subsection{SHALLOW AMPLITUDE ANOMALIES: POSSIBLE EVIDENCE OF A NATURAL GAS HYDRATE SYSTEM}

Within the 3D seismic volume, we detected nine main areas (areas I-IX), characterised by enhanced amplitude reflections in the Late Oligocene to present day succession covering a total extent of $59 \mathrm{~km}^{2}$ (Figs. 1, 4). The main characteristics of each area are summarised in Table 1. These areas are composed of either a single patch, or separate $\mathrm{km}$-sized patches, of enhanced amplitude reflections ('soft', 'hard', or both).

In five cases (areas I, III, IV, VII, IX see Figs. 6, 7, and Tab. 1), the geometry of the upper portion of these high amplitude anomalies exhibits a bottom-simulating character, with a polarity that appears opposite to that of the seabed, occasionally cross-cutting stratigraphic reflections (Fig. 6C). These BSRs are underlain by intervals of stacked enhanced reflections $~ 20-150 \mathrm{~ms}$ TWT in thickness (Figs. 6, 7). These characteristics allow us to interpret these patchy BSRs as the BGHSZ, with the underlying enhanced reflections being the free gas zone. Assuming bulk stability conditions and a pure methane hydrate-forming gas, the depth of the BGHSZs would reflect geothermal gradients comprised 45 and $60^{\circ} \mathrm{C} / \mathrm{km}$ (Fig. 6). Data from industry wells in the study area and nearby regions suggest geothermal gradients ranging from approximately 32 to $45^{\circ} \mathrm{C} / \mathrm{km}$ (taking $5^{\circ} \mathrm{C}$ as an average seafloor temperature, Fig. 8), whereas shallow temperature measurements at ODP Sites 762 and 763 suggest higher gradients for the first $\sim 150 \mathrm{~m}$ of sediment $\left(\sim 55-65^{\circ} \mathrm{C} / \mathrm{km}\right.$, assuming linear gradients, and the temperature data reported in Swift et al., 1992; Fig. 8). The choice of a pure methane hydrate-forming gas and possible causes for this discrepancy between the geothermal gradient predicted by the position of the interpreted BGSHZ and that extrapolated from in-situ data are discussed below (section 5.3). 
6

We further observed enhanced 'hard' reflections above the interpreted BSRs (Fig. 6), which often occur along irregular and/or mounded horizons (Figs. 6, 9). These amplitude anomalies can be either limited to a few stratigraphic reflections (e.g. Fig. 6A), or vertically stacked over depths of more than 200 ms TWT with high amplitude patches separated by stratigraphic reflections with background amplitude (e.g. Figs. 9A, B). The lateral distribution of such anomalies is similar to that of the deeper 'soft' reflections interpreted as free-gas bearing sediments (see Figs. 4, 5). In some cases, we identified undisturbed stratigraphic intervals separating these amplitude anomalies (e.g. Figs. 6A, 9A), whereas elsewhere these 'soft' and 'hard' enhanced reflection meet at the interpreted BGHSZ (e.g. Fig. 6C). The enhanced 'hard' reflections are interpreted as evidence either of hydrate accumulations at elevated concentrations, or of deposits of authigenic carbonate minerals. The irregular/mounded morphology of the stratigraphic reflections that accompanies the increase in amplitude could indicate volume expansion related to hydrate formation. This effect has been observed in other gas hydrate provinces associated with localised leakage of hydrocarbons (cf. Paull et al., 2008a; Riboulot et al., 2016; Marsset et al., 2018). However, a deformed seafloor owing to sedimentary processes in areas affected by MTDs (cf. Scarselli et al., 2013) could account for the morphology of these anomalies without the need to invoke volume expansion. In some places, the shallow amplitude anomalies lack a proper BSR-like character, and only a series of discontinuous 'soft' and 'hard' reflections, intersected by small-offset faults, are observed (Fig. 9). The seafloor morphology above areas characterised by shallow amplitude anomalies is relatively rough and punctuated by depressions interpreted as pockmarks (Figs. 6, 7B, 9).

It is important to mention that the occurrence of carbonate platforms and reefs is welldocumented in the Mid Miocene along the NW Shelf of Australia and the Timor Sea, also in association with hydrocarbon seepage from deep reservoirs (Hovland et al., 1994; Bailey et al., 2006; Logan et al., 2010). These carbonate structures can result in enhanced seismic reflections (Feary and James, 1995; Ryan et al., 2009; Goktas et al., 2016). However, the Exmouth Plateau, in 
6

contrast with the shelf area, was characterised by pelagic deposition rather than carbonate platform and reef environments throughout the Miocene (Exon et al., 1992), and therefore was an unlikely location for a shallow-water carbonate platform. Nevertheless, we do not exclude that paleo- to present-day deep-water coral (azooxanthellate) mounds could be an alternate explanation for the observed enhanced 'hard' amplitude reflections in this region (cf. De Mol et al., 2002; Roberts et al., 2006a). Such a hypothesis does not preclude the presence of a present-day natural gas hydrate system in the area.

\subsection{DEEP ACCUMULATIONS OF HYDROCARBONS}

At least fifteen groups of DHIs within the upper portion of the Mungaroo Fm. (Unit 1) have been detected and mapped in the study area (Figs. 1b, 4). These DHIs are seismically expressed as enhanced 'soft' reflections, characterised by a basal amplitude shut-off contact, and a geometry which occasionally visibly conforms to the structure, suggesting an internal connection of the hydrocarbon phase (e.g. Figs. 3A, B, 9A). These enhanced reflections are frequently stacked over depths of hundreds of ms TWT within the Late Triassic Mungaroo Fm. (Unit 1) in footwall blocks, indicating the occurrence of stacked hydrocarbon-bearing units, as confirmed by drilling (e.g. Eendracht-1 and Brederode-1, Esso Australia Ltd, 1981b; Chevron Australia Pty Ltd, 2011b, Fig. 3A, B). In other cases, we observed clear hydrocarbon-water contacts, expressed as a flat or slightly dipping reflection, having polarity equal to that of the seafloor, and cross-cutting the stratigraphy (e.g. the Thebe, Kentish Knock, and Kentish Knock South discoveries; BHP Billiton Petroleum Pty Ltd, 2008; Chevron Australia Pty Ltd, 2010b; Chevron Australia Pty Ltd, 2014, Figs. 3C, D, 7).

The genesis of the traps associated with these DHIs is related to the geometries of the Upper Triassic extensional faults, capable of producing three-dimensional horst-like and footwall block structures (Figs. 3, 7, 9A). The observed DHIs are similar to those reported in other portions of the NW Shelf of Australia, including the nearby Exmouth Sub-Basin and Rankin Trend (see Cowley and O'Brien, 2000; Longley et al., 2002; Bailey et al., 2006), as well as in other basins characterised 
by rifting and normal faulting (e.g. the North Sea and the Barents Sea, Spencer and Larsen, 1990; Hermanrud et al., 2014).

The top sealing interval for these hydrocarbon accumulations is constituted by the uppermost deposits of the Mungaroo Fm. (Unit 1) and by the Brigadier Fm. (Unit 2), which are dominated by transgressive marine calcareous claystones and fine-grained calcilutites that drape the underlying fluviodeltaic depositional system. This interval is punctuated by circular depressions, which are focused along the footwall of the major tectonic faults and are interpreted as paleo-pockmarks (Figs. 4A, B, 9A). The distal deposits of the Barrow Group (Unit 4) and, where present, the condensed Jurassic sequence (Athol Fm. and Dingo Claystone, Unit 3) constitute additional seals. Intra-seal units further exist between stacked gas-bearing reservoirs within the Mungaroo Fm (Unit 1). The Early Cretaceous Muderong Shale (Unit 5) represents the regional top seal. The lateral seals are constituted by different units, depending on the juxtaposition relationships along the bounding faults and, potentially, by the fault zones themselves. In the case that reservoir intervals are juxtaposed on the two sides of a fault, this may limit the capacity of a trap (e.g., Kentish Knock South) (BHP Billiton Petroleum Pty Ltd, 2008; Chevron Australia Pty Ltd, 2010b, 2011b, 2013c, 2014). The main seismic characteristics of the traps associated with these DHIs, as well as their associated petroleum system and leakage evidence, are summarised in Table 2.

In the NW portion of the study area, the top of the Mungaroo Fm. (Unit 1) is further characterised by enhanced reflectivity (Fig. 9D, E). The mapped horizon (top of Unit 1, approximating the boundary between the Mungaroo Fm. and the Brigadier Fm.) is characterised, at the crest of a prominent fault block with extensive erosion of the footwall, by increased amplitudes (cf. Fig. 9D, E, with 10A). It is difficult to establish the nature of this amplitude anomaly (i.e. lithological or owing to hydrocarbon fluids), given that it is stratigraphically confined to a single reflection, and its lateral extension does not appear to conform to the structure. The amplitude of 
this horizon is similarly enhanced along other footwall blocks, although with lesser contrast (Fig. 9A).

\subsection{SEISMIC BLANKING AND ENHANCED REFLECTIONS BETWEEN THE UPPER} TRIASSIC AND THE UPPER OLIGOCENE

The stratigraphic reflections in the interval between the Upper Triassic fault blocks and the shallow amplitude anomalies described earlier (see sections 4.2, 4.3) are, in some places, characterised by vertical zones of seismic attenuation and reduced frequency content, as well as evidence of reflection disruption, and up-bending of the adjacent reflections (Figs. 6B, C, 9A, B). The lowermost boundary of these vertical zones of seismic 'blanking' coincides with the crestal (i.e. the structurally highest) portions of the footwall blocks, at the top of or within the Mungaroo Fm. (Unit 1). The presence of free gas in the sediment pore space is well-known to cause an overall loss of seismic data quality observed effect on seismic data, and the vertical migration of fluids has often been associated with the disruption of stratal continuity (see Arntsen et al., 2007; Cartwright et al., 2007; Løseth et al., 2009; Plaza-Faverola et al., 2011; Andresen, 2012). Therefore, these vertical blanking zones are interpreted to indicate sediment volumes affected by the cross-stratal migration of hydrocarbons. However, we cannot exclude that the shallow amplitude anomalies themselves, could have contributed to the underlying seismic signal degradation, by creating scattering, attenuation, reflection distortion, and transmission artefacts (see Cartwright and Santamarina, 2015).

In addition, enhanced stratigraphic reflections have been identified at stratigraphic positions comprised between the base of the Muderong Shale (Unit 5, Early Cretaceous) and the top of the Miria Marl equivalent (Unit 7, Late Cretaceous), or the lower portion the Dockrell Fm. (Unit 8, Paleocene-Early Eocene) (Fig. 6A, 9). These amplitude anomalies can be organised as (1) continuously stacked enhanced reflections, (2) multiple clusters of reflections connected by faults but stratigraphically separated by low-reflectivity layers, or (3) individual pairs of enhanced 
6 406 8 407 11

reflections (cf. Foschi et al., 2014 and 2017). The polarity of these enhanced reflections suggests a decrease in acoustic impedance and, therefore, are interpreted as accumulations of free gas. These amplitude anomalies extend up-dip in the SE portion of the study area, where they partly overlie three separate structural highs showing evidence of deeper DHIs and underlie three areas with shallow anomalies (cf. Figs. 4B, 5). The thickness of the interval comprised between the top of the Mungaroo Fm. (Unit 1) and the top of Unit the Muderong Shale (Unit 5) increases to more than 500 ms TWT ( 550-600 m) towards the SE, with no evidence of deep DHIs at the crests of the Upper Triassic fault blocks (Fig. 7).

\subsection{CONTROLLING FACTORS ON THE DISTRIBUTION OF SHALLOW ANOMALIES \\ 4.4.1. Structural features and deep DHIs distribution}

The shallow amplitude anomalies interpreted as indicative of free gas and hydrate-bearing sediments are always located above the topographically higher portion of the footwalls of the riftrelated normal faults and, in some cases but not exclusively, directly above the zones of fault linkage in the vicinity of Upper Triassic relay ramps (Fig. 4A, B). The reflections indicative of free gas within the broadest shallow amplitude anomaly (areas III and IV, Fig. 6B, C) have a down-dip limit which appears to be controlled by the location of the structurally highest areas of the underlying Upper Triassic footwall blocks. In contrast, these reflections extend up-dip along a gradient which seems to be defined by the three-phase boundary, i.e. the BGHSZ.

In four cases, the DHIs observed in the Mungaroo Fm. (Unit 1) are directly overlain by shallow amplitude anomalies, which occur above the structurally highest portion of the interpreted hydrocarbon accumulations (e.g. the Brederode and Kentish Knock South traps, see Tab. 2). In other cases, the seismic blanking zones underlying the shallow anomalies pervasively extend down within the Triassic fault blocks (Fig. 6B, C), precluding a confident identification of deeply rooted amplitude anomalies indicative of free gas accumulations. 
6 430 8

The presence of stacked enhanced reflections along deep tectonic faults within the Cretaceous to Early Paleogene stratigraphy (Units 5-8) suggests that some faults acted as pathways for the migration of hydrocarbon gases (Figs. 6A, 8). However, there is not a clear relationship between the occurrence of shallow amplitude anomalies and the areas of maximum displacement of the underlying Upper Triassic fault blocks. Although the faults associated with the most extensive shallow amplitude anomalies are those with the most significant displacements (in excess of $600 \mathrm{~ms}$ TWT at the Top Triassic interval), slightly smaller displacements (up to $\sim 500 \mathrm{~ms}$ TWT at the Top Triassic interval) are observed in the eastern side of the study area, where numerous deep DHIs are detected (including the DHI indicating the Thebe accumulation), without clear evidence of shallow amplitude anomalies (cf. Figs. 3D, 6B, C). In contrast, the other DHIs (e.g. those related to the Brederode and Kentish Knock South accumulations), as well as the other shallow amplitude anomalies are associated with smaller displacements (Figs. 3A, 7).

\subsubsection{Thickness of sealing units for deep hydrocarbon accumulations}

The vertical thickness of the sediment package between the top of the Mungaroo Fm. (Unit 1) and the top of the Muderong Shale (Unit 5) (Fig. 10B) varies from 0 to $1200 \mathrm{~ms}$ TWT, and appears a critical controlling factor, but not the only one, for the distribution of the interpreted distribution of shallow free gas and gas hydrates. Areas where this interval is either absent or extremely thin (i.e. less than $\sim 50 \mathrm{~ms}$ TWT) are in fact commonly associated with the occurrence of shallow anomalies. In the NW portion of the study area, at the crest of the Upper Triassic fault blocks, this sequence is completed eroded, and the Mungaroo Fm. can directly underlie Paleogene sediments (Fig. 9C-E).

Shallow anomalies have been observed in the case of both reservoir-fault and reservoirunconformity juxtapositions (Figs. 6A, 7, 9A and Tabs. 1, 2). Therefore, the presence of an erosional unconformity, expressed by numerous footwall scarps, at the top of possible reservoir 
intervals in the Upper Triassic, or the occurrence of reservoir-reservoir juxtapositions across a fault surface, could also control the presence and distribution of shallow anomalies.

\subsection{GEOCHEMICAL EVIDENCE}

Geochemical data acquired at ODP Site 762 includes porewater values of sulphate, chloride, the total carbonate content of the sediment, as well as the TOC and headspace methane gas concentrations (Fig. 11) (see Haq et al., 1990; De Carlo, 1992; Snowdon and Meyers, 1992). No seismic amplitude anomalies were penetrated during drilling at this site (Fig. 11F). The values of sulphate in pore waters indicate a $\sim 75 \%$ reduction at $\sim 370$ mbsf and nearly zero sulphate at $\sim 550$ 600 mbsf (Fig. 11A). Chloride values slightly decrease with depth, down to approximately 800-830 mbsf, at the lithological boundary between the Muderong Shale and the Windalia Radiolarite/Lower Gearle Siltstone (Units 5-6), which marks a transition from carbonate-dominated (Unit 6 and younger) to siliciclastic (Unit 5 and older) sediments (De Carlo, 1992) (Fig. 11B). Therefore, a sharp upward increase in sediment carbonate, but also a decrease of the TOC, are observed from Unit 5 to Unit 6 (Fig. 11C, D) (Haq et al., 1990; Snowdon and Meyers, 1992). Headspace methane concentration abruptly increase to values of over $10^{3}$ ppm below depths of $\sim 370-400$ mbsf, and values higher than $10^{4}$ ppm occur at $\sim 500-800$ mbsf (Fig. 11E). Compositionally, the headspace gas is dominated by methane (>99\%), with small amounts of $\mathrm{C}_{2+}$ hydrocarbons increasing with depths (Snowdon and Meyers, 1992).

Gas compositions in the drilled Upper Mungaroo reservoirs in the study area are characterised by carbon isotopic values indicative of both a thermogenic origin $\left(\delta^{13} \mathrm{C}_{\mathrm{CH} 4}\right.$ and $\delta \mathrm{D}_{\mathrm{CH} 4}$ of $-47.6 \%$ to $39.8 \%$ and of $-215 \%$ o to $-182 \%$, respectively) and potential biodegradation (positive $\delta^{13} \mathrm{C}_{\mathrm{CO} 2}$ values) (Fig. 12). Furthermore, the amount of methane in these reservoir gases increases up to $>99 \%$, relative to $\mathrm{C}_{2+}$ hydrocarbons, towards the top of the Upper Mungaroo reservoir intervals (BHP Billiton Petroleum Pty Ltd, 2008; Chevron Australia Pty Ltd, 2010b, 2011b, 2013b, 2014), 
475 approaching compositions resembling those measured within shallower stratigraphic units at ODP 1 476 Site 762 . 


\section{Discussion: a natural gas hydrate system on the Exmouth Plateau}

\subsection{SOURCE}

The shallow seismic amplitude anomalies interpreted to reflect an NGHS are discontinuously distributed in the study area (e.g. Figs. 1B, 4B). The shallow depth, polarity, and lateral extent of these amplitude anomalies (e.g. Fig. 6) suggest the occurrence across the Exmouth Plateau of kmsized patches of free gas trapped beneath the base of gas hydrate stability, and potential hydrate accumulations above this boundary. The discontinuous distribution of the shallow amplitude anomalies indicates that the presence of hydrate-forming gases exceeding their saturation in the pore waters is not ubiquitous within the study area, but instead heterogeneous within and immediately beneath the BGHSZ. The low methane concentrations in the pore waters and the low TOC of the shallow $(<\sim 400 \mathrm{~m})$ sediments at ODP Site 762 further support this interpretation, by showing lack of favourable conditions for hydrate formation away from zones characterised by shallow seismic amplitude anomalies (Fig. 11D, E).

Thus, the available geochemical data suggest that the first hundreds of metres of sediment do not host a ubiquitous and effectively producing microbial methane pool. This interpretation fits well with the stratigraphic history of the study area, which has been characterised by low sedimentation rates and lack of a terrigenous input from the continent since the Late Cretaceous, resulting in a deepwater carbonate-dominated stratigraphic section in the last $\sim 100$ million years (Fig. 11C). These two factors have discouraged the accumulation and preservation of organic matter in the shallow sediments (cf. Müller and Suess, 1979; Wallmann et al., 2006).

The occurrence of amplitude anomalies related to shallow free gas and hydrates right above deeper structural highs (Figs. 6, 7, 9) suggests that the increased concentration of hydrocarbon gases within and immediately beneath the GHSZ is controlled by structural elements. Some of the structural highs further constitute effective traps for thermogenic dry and biodegraded gas (BHP 
Billiton Petroleum Pty Ltd, 2008; Chevron Australia Pty Ltd, 2010b, 2011b, 2013b, 2014), likely sourced by coaly source rocks of Mid to Upper Triassic age (Longley et al., 2002) (Fig. 12). Thus, in the absence of effective sealing lithologies for the Upper Mungaroo gas accumulations (i.e. within Unit 1), it is possible that an NGHS can form at shallow depth due to the focused leakage of thermogenic gases from deeply-seated structural focal areas. In this scenario, the migrating thermogenic gases, before entering the GHSZ, could be temporarily stored in a series of reservoirs, including Upper Triassic and Cretaceous sediments, as well as within the free gas zone directly underneath the BGSHZ. In the last 15-20 years, NGHSs sourced by thermogenically-generated hydrocarbons, including systems characterised by deep leaky traps, have been observed in different basins, including the Northern Gulf of Mexico, the North Alaskan permafrost, the Barents Sea, the Niger Delta, the Lower Congo Basin, and the NW Borneo (Sassen et al., 2001; Collett et al., 2011; Ostanin et al., 2013; De Prunelé et al., 2017; Paganoni et al., 2018), highlighting the fact that thermogenic petroleum systems may play a critical role in natural gas hydrate formation in a variety of geological settings.

However, it is not possible to exclude a contribution of biogenic gas to the formation of the observed shallow amplitude anomalies, with this gas being potentially generated from diagenesis of the organic matter present in the Barrow Group, the Muderong Shale, and the Gearle Siltstone equivalent (Units 4-6, see the increase in TOC with depth in Fig. 11D). Note also that extremely elevated TOC values (9-15\%) have been measured in nearby ODP Site 763 within a thin stratigraphic interval marking the Cenomanian-Turonian event (Snowdon and Meyers, 1992). A further potential source for biogenic gas in the study area could be constituted by the Jurassic Dingo Claystone (Unit 3), which is a mature source rock in the nearby Exmouth sub-basin (BHP Billiton Petroleum Pty Ltd, 2010). 


\subsection{RESERVOIR}

The interpreted hydrate-bearing sediments in this area occur in the first $\sim 150-200 \mathrm{~m}$ of overburden and belong to Unit 9 and the uppermost part of Unit 8 defined in this study. These units partly correlate with Units I and II described at ODP Site 762. Hence, these sediments, which range in age from the Late Eocene-Early Oligocene to the present day, are represented by pelagic foraminifera, and nannofossil-rich carbonate oozes, which become more consolidated with depth (Haq et al., 1990). Sediment remobilisation due to submarine slope failures in this area (Scarselli et al., 2013) could have further modified the nature of the gas hydrate-bearing sediments, in particular impacting their consolidation and permeability.

It is possible that in fine-grained lithologies hydrates occur with grain-displacing morphologies (see Cook et al., 2008, 2014). However, the presence of foraminifers could favour the precipitation, within their chambers, of hydrates with pore-filling habits (Li et al., 2016). Regardless of this uncertainty, if the enhanced 'hard' reflections within the GHSZ represent hydrate-bearing sediments (Figs. 6, 7, 9), they would indicate that hydrates occur at concentrations capable of impacting the reflectivity of the stratigraphy and, possibly, enhancing its volume (Paull et al., 2008a; Boswell et al., 2016). To reduce these uncertainties and better understand the distribution of hydrates within these sediments, the acquisition of shallow core and well-log data is necessary.

\subsection{STABILITY CONDITIONS}

The choice of a pure methane hydrate structure I phase boundary to model the BGHSZ in the study area is justified by the presence of methane-dominated gas in the deep Upper Triassic reservoirs $\left(C_{1} \sim 95-99 \%\right.$, see section 4.5 and Fig. 12A), with gas compositions approaching pure methane towards the top of the Mungaroo Fm. (Unit 1), as indicated by mud gas log, isotubes and Modular Dynamic Formation Tester (MDT) data (BHP Billiton Petroleum Pty Ltd, 2008; Chevron Australia Pty Ltd, 2010b, 2011b, 2013b, 2014). A progressive enrichment of methane over ethane 
towards shallower depths was also observed within more recent sediments at ODP Sites 762 and 763 (Snowdon and Meyers, 1992; Meyers and Snowdon, 1993).

The depth of the interpreted BSRs, taken as the base of gas hydrate stability, suggests relatively high geothermal gradients in this area $\left(\sim 45-60^{\circ} \mathrm{C} / \mathrm{km}\right)($ Fig. 6). The temperatures measured down to $\sim 150 \mathrm{~m}$ at ODP Sites 762 and 763 (Swift et al., 1992) suggest shallow geothermal gradients of $\sim 55-65^{\circ} \mathrm{C} / \mathrm{km}$ (assuming linear gradients), which partly align with those extrapolated from BSRs depths. However, our results do not match the gradients $\left(\sim 32-45^{\circ} \mathrm{C} / \mathrm{km}\right)$ estimated from in-situ temperature data acquired at $\sim 850-3980$ mbsf within several industry boreholes across the Exmouth Plateau (Fig. 8). The difference between geothermal gradients from the extrapolated depths of BSRs, ODP and industry data may simply reflect the variation in the thermal conductivity of the shallower $v s$ deeper sediments, which ultimately impact the temperature gradients (Stranne and O'Regan, 2016).

Nevertheless, it is also possible that the rapid expulsion of relatively warm hydrocarbon fluids from deep reservoirs could contribute in creating high geothermal gradients, and shifting the BGHSZ upward, as inferred in areas of active fluid advection (Taylor et al., 2000; Pecher et al., 2010; Laird and Morley, 2011; Crutchley et al., 2014). Alternatively, if the pelagic carbonate oozes within the GHSZ have pores tens to hundreds of nanometres wide, the BGHSZ could shift upward owing to the Gibbs-Thomson effect (i.e. the change of methane solubility and stability conditions within narrow pore networks with respect to bulk conditions, cf. Clennell et al., 1999; Henry et al., 1999; Uchida et al., 2002; Anderson et al., 2003). The validation of these hypotheses would require the acquisition of shallow temperature and heat flow data, as well as the recovery of shallow cores. More generally, the entire kinetics of hydrate nucleation and growth, as well as the capillary effects on both the hydrate and free gas phases, need to be evaluated to assess the thermodynamic nature of the three-phase boundary. 
The seismic velocity used to plot the theoretical depths of the BGHSZ in the TWT seismic data constitutes a further source of uncertainty. The presence of high-velocity hydrate-rich layers within the GHSZ, for example, could result in an underestimation of the effective depth of the BGHSZ.

\subsection{HYDROCARBON PLUMBING SYSTEM}

The interpretation of the seismic data suggests a relationship between deep structures and the distribution of the shallow amplitude anomalies (Fig. 4B). The fact that the units supposed to seal the deeply-generated thermogenic gases within Upper Triassic reservoirs (Unit 1) are condensed or absent beneath the most prominent shallow amplitude anomalies (Figs. 6B, C, 9B-E) supports the interpretation of a system where thermogenic fluids leak towards the shallow portions of the basin to feed the GHSZ. In these cases, significant erosion and non-deposition of Upper Triassic and Jurassic sediments at the footwall blocks is proposed to have resulted in a less effective top seal for any hydrocarbons stored within the Mungaroo Fm. In other cases, we envisage a combination of potentially leaky faults and stratal pathways between the Upper Triassic and the shallow amplitude anomalies (Figs. 6A, 7). The nature of juxtaposing lithologies along a fault, as well as the permeability of fault zones and carrier beds, represent the critical elements to evaluate for each structure. Thus, the occurrence of ineffective sealing lithologies, conductive faults, and permeable stratal pathways in the stratigraphy comprised between the Upper Triassic and the Tertiary are interpreted as critical elements for the formation of gas hydrates and shallow free gas in the study area. The polygonal fault system identified between the Upper Cretaceous and the Mid Miocene (Units 7-8, Figs. 3, 5C-E) could have played a role in favouring the cross-stratal migration of hydrocarbons towards the BGHSZ (cf. Dirstein et al., 2013). However, we did not observe any amplitude anomaly associated explicitly with such faults.

Surprisingly, a spectrum of high-amplitude anomalies indicative of free gas-bearing sediment is observed in the Lower to Upper Cretaceous sediments (Units 5-7, Fig. 7), which are known to be 
fine-grained in this area. In particular, the Muderong Shale is considered a good-quality sealing formation (Dewhurst et al., 2002). However, the occurrence of amplitude anomalies within it may indicate the presence of significant variations in its fluid flow properties, which may compromise its integrity as a regional seal. Another factor that can compromise the extent to which the fine-grained sediments in the study area act as seals for underlying hydrocarbon accumulations is the presence of pre-existent fractures and faults (Dewhurst and Hennig, 2003). Moreover, the Windalia Radiolarite, which stratigraphically overlies the Muderong Shale, is inferred to be a 'thief zone' by Bailey et al. (2006) and could represent another interval which favours the leakage of hydrocarbons in the area.

In the deepwater portions of the Northern Carnarvon Basin, the potential formation of hydrates within the GHSZ can partly buffer the seepage of gas to the seafloor. Therefore, the release of hydrocarbons to the water column could be modulated by processes such as hydrate recycling, dissociation and dissolution, although elevated rates of seepage from deeper leaky reservoirs could allow gases to enter the water column without complete conversion into hydrate (Chen and Cathles, 2003; Smith et al., 2014; Andreassen et al., 2017). The observation of pockmarks above the shallow amplitude anomalies supports an ongoing migration of gas towards the seafloor and the water column (Figs. 6B, C, 9). Similarly, the nearby Scarborough and Jupiter gas accumulations are overlain by shallow anomalies and seafloor morphological evidence of recent gas seepage (Cowley and O'Brien, 2000).

The interpretation of an NGHS fed by hydrocarbon leakage from deeper sources implies the involvement of one or multiple mechanisms capable of allowing hydrocarbons to by-pass the postTriassic sedimentary sequence, up to the BGSHZ. These mechanisms may include (1) capillary invasion through the primary pore space, (2) advection along a fracture network, and (3) advection along faults. These processes can occur, respectively, where the top of a hydrocarbon-bearing unit is overlain by relatively permeable stratigraphic, fracture-, and fault-related pathways. The third mechanism implies that the hydrocarbon-bearing unit is adjacent to a permeable fault, which would 
limit the maximum thickness of a hydrocarbon column, and the lateral extension of a gas reservoir (cf. Hermanrud et al., 2014). The observation in seismic data of (1) seismically degraded stratigraphic reflections separating the shallow anomalies from the deep fault blocks (Figs. 6B, C, 9A, B), (2) stacked enhanced reflections surrounding tectonic faults (Figs. 6A, 7), (3) small-offset discontinuities associated with shallow anomalies (Fig. 9C-E), and (4) enhanced reflections extending for kilometres along the same stratigraphic horizons (Fig. 7), suggests that all three of these processes occur in the study area, with a capillary invasion mechanism throughout the primary pore space being controlled by the intrinsic physical properties of the sediments. The other mechanisms would instead be favoured by the development of syn/post-depositional discontinuities (i.e. faults and fractures). The occurrence of shallow anomalies immediately overlying fault intersections and relay ramps in the Upper Triassic stratigraphy (Fig. 4A, B) also highlights the potential role of these zones as focusing points for hydrocarbon migration, compromising the integrity of hydrocarbon-bearing reservoirs, a phenomena widely observed further north on the NW Shelf of Australia, in the Timor Sea (e.g. Gartrell et al., 2004).

Based on the above discussion and the observations presented in this study, we suggest a conceptual model (Fig. 13) where thermogenic hydrocarbons leak towards the GHSZ through a combination of faults, fracture, and stratal pathways. Depending on the interplay between the reservoir and sealing units, hydrocarbons may be trapped at different levels during the process of migration from their source rock(s), including in the potentially commercial accumulations drilled in the study area.

The presence of amplitude anomalies indicative of an NGHS in the study area, in conjunction with the deeper evidence of free gas, the seafloor expressions of gas seepage, and the occurrence of seismic blanking zones terminating immediately beneath the interpreted NGHS, further indicate that the hydrocarbon plumbing system is currently active in the study area, with methane fluxes being high enough to result in the formation of seismically visible hydrates or authigenic carbonates, 
6

pockmarks, and BSR-like amplitude anomalies. This interpretation, in conjunction with the recent discovery of Upper Triassic-Late Jurassic paleo-pockmarks in this area (Dirstein et al., 2013; Velayatham et al., 2018, see also Figs. 4A, B, 9A), and the potential identification of a paleoNGHS in the Paleocene-Eocene sediments of the nearby Barrow sub-Basin (Imbert and Ho, 2012), suggests that the Exmouth Plateau is a region with a long-term history of hydrocarbon generation and expulsion events, where the onset of generation from Mungaroo Fm. source rocks is predicted to be in the Late Triassic-Early Jurassic from geochemical analysis (Cook et al., 1985), and peak generation expected at present day at 5000 mbsf (Geoscience Australia, 2014).

Regardless of the exact source of the hydrate-forming gases, the observed distribution of shallow amplitude anomalies (including BSRs) controlled by deep structures, and occurring within a lithologically homogeneous stratigraphy, provides evidence for a potential NGHS sourced by gas generated below the BGHSZ. A similarly 'patchy' structurally-controlled distribution of shallow gas anomalies has been observed in the Barents Sea, where a thermogenically-sourced natural gas hydrate system overlies deep hydrocarbon traps analogous to those described in this study (cf. Ostanin et al., 2013). Likewise, other hydrocarbon provinces with different structural styles, such as the fold-and-thrust belt offshore Sabah (Paganoni et al., 2018), as well as the Green Canyon and Mississippi Canyon areas in the Northern Gulf of Mexico (Sassen et al., 2001; Roberts et al., 2006b; Simonetti et al., 2013), display isolated patches of shallow amplitude anomalies overlying deeper hydrocarbon reservoirs.

The data and results presented here are relevant to the study of the petroleum system in the NW Shelf, in terms of charge and migration history. Future detailed geometric analyses on the faults associated with amplitude anomalies in this area could provide better insights into the role of the present-day state of stress on fluid flow (Bailey et al., 2016b). The ultimate triggers for hydrocarbon migration towards the GHSZ could encompass many mechanisms, all capable of critically pressuring deep hydrocarbon reservoir, up to a point that would result in seal failure. 
6

675 8

These mechanisms need to be analysed in detail in future work and include (1) an active hydrocarbon charge from source rocks resulting in a valve-like behaviour of the sealing lithologies and faults, (2) fault reactivation, (3) vertical and lateral overpressure transfer, and potentially (4) generation overpressures in the reservoirs caused by sea-level falls (see Clennell et al., 2000; Wiprut and Zoback, 2000; Yardley and Swarbrick, 2000; Cartwright et al., 2007; Tingay et al., 2007; Langhi et al., 2010; Hermanrud et al., 2013).

\section{Conclusions}

This study has documented the potential occurrence of a natural gas hydrate system in the Exmouth Plateau, on the NW Shelf of Australia. This system is characterised by the presence, in 3D seismic reflection data, of high amplitude anomalies indicative of shallow free gas accumulations beneath the base of the gas hydrate stability zone, in conjunction with amplitude anomalies within the stability zone that suggest the presence either of hydrates at elevated saturations or of authigenic carbonates. The interpreted gas hydrate-bearing sediments are constituted by deepwater carbonate nannofossil, and foraminifera oozes.

Based on the distribution of the observed amplitude anomalies with respect to the deeper structures, and considering geochemical evidence indicating the absence of a shallow microbial gas source in the study area, the hydrate-sourcing gas is interpreted to be of thermogenic origin, most likely generated within the Mungaroo Fm. The same gas sources several seismically visible deep gas reservoirs, some of them successfully drilled by exploration boreholes.

The thermogenic hydrate-forming gas is interpreted to have migrated from Upper Triassic fault blocks through a combination of cross-stratal and stratal pathways. Seismic evidence for this is provided by stacked high amplitude anomalies, in some cases intersected by tectonic faults, and blank zones within the stratigraphic intervals underlying shallow high amplitude anomalies. 
The potential presence of a natural gas hydrate system in the NW Shelf of Australia adds a

1

\section{Acknowledgements}

We would like to thank Schlumberger for allowing us to use the Petrel software, Geoscience Australia for the access to the National Offshore Petroleum Information Management System (NOPIMS), and the 3D seismic data. All the industry well and seismic information shown in this work are based on Geoscience Australia material. We finally thank all the reviewers and the editor of this journal for their suggestions, which helped in improving the quality of this manuscript. 
Figure 1. A) Simplified bathymetric map of the Exmouth Plateau and surrounding areas (modified after Exon et al., 1992). Bathymetry is expressed in kilometres below the sea level; F.Z.= fracture zone. The blue polygon represents the perimeter of the Bonaventure 3D survey. The location of the hydrocarbon exploration wells used in this study and of the ODP Sites 762 and 763 (Leg 122) are also indicated. The inset map at the top-left portion indicates the location of the study area along the NW Shelf of Australia $(\mathrm{WA}=$ Western Australia; NT $=$ Northern Territory; SA $=$ South Australia; QLD $=$ Queensland; NSW= New South Wales; VIC= Victoria; TAS= Tasmania). B) Blended TWT and variance seafloor map of the area investigated by the Bonaventure 3D survey. Exploration wells and ODP Site 762 are indicated $(\mathrm{Ee}=$ Eendracht $-1 ; \mathrm{Br}=$ Brederode-1; Ar= Arnhem-1; KK= Kentish Knock-1; KKS= Kentish Knock South-1; Th1= Thebe-1). The map also shows the projections at the seafloor of interpreted shallow anomalies (gas hydrates/authigenic carbonates and shallow free gas), as well as the deep DHIs identified in the Mungaroo Fm and the lateral extent of the stacked enhanced reflections between Units 5 and 7 in the SE portion of the study area. The projected location of the Scarborough accumulation (reservoir in the Barrow Group) is also shown in the SE part of the figure. HS= headwall scarp related to the occurrence of seafloor mass-transport deposits (MTDs). The black arrows indicate circular seafloor depressions at the margins of the MTDs.

Figure 2. Composite stratigraphic column for the study area (modified after Exon et al., 1992; Black et al., 2017). Both the main tectonic and petroleum system elements are shown. FGZ= free gas zone (i.e. shallow free gas reservoir); GHSZ= gas hydrate stability zone; C-T OAE= Cenomanian-Turonian Oceanic Anoxic Event. The numbers from 1 to 9 indicate the stratigraphic units defined in the seismic data for this study. All the free gas accumulations identified between Unit 5 and the top of Unit 8 are referred to as 'intermediate gas reservoirs'.

Figure 3. A-D) Interpreted seismic sections passing through exploration wells in the study area. The inset map in (A) shows the location of the sections. The definition of stratigraphic units 1-9 is based on well calibration. Note the extremely thin Jurassic stratigraphy, as well as the significant changes in thickness of the Brigadier Fm.-Muderong Shale interval (Units 2-5) between structural highs and lows. The blue arrows indicate DHIs in the Mungaroo Fm., interpreted as accumulations of free gas, as confirmed by drilling. Faults are highlighted by red lines: $\mathrm{PFS}=$ polygonal fault system; TF= tectonic faults (rift-related extension). The stratigraphic position of the horizon shown in Fig. 5D (P), interpreted to be Paleocene in age (Dockrell Fm.), is shown in the simplified stratigraphic column on the right of each section.

Figure 4. A) Blended TWT and variance map of the top of Unit 1 (top Mungaroo Fm-base Brigadier Fm., Late Triassic). Note the prominent NNE-SSW trending fault blocks, as well as the numerous fault linkage and relay ramp structures. The red circles and ellipses indicate the approximate location of the areas showing seismic evidence of shallow leakage of hydrocarbons. B) Variance map of the top of Unit 1 (top Mungaroo Fm-base Brigadier Fm.). This map shows the projected locations of areas characterised by shallow leakage of hydrocarbons (I-IX), those of the deep DHIs in the Mungaroo Fm. (1-15), and that of the enhanced reflections stacked between Unit 5 and Unit 7 (Muderong Shale-Miria Marl equivalents) (cf. Figs. 3, 6, 7, 9). The projected location of the Scarborough accumulation (reservoir in the Barrow Group) is also shown in the SE part of the figure. The paleo-pockmark observable in Fig. 9A is shown in the blow-up at the bottom of (B) (see black arrow). Other paleo-pockmarks are identified as small circular depression, with high variance. C) Rose diagrams illustrating the azimuths of preferred fault plane strikes for a total of 727 faults mapped at the top of Unit 1 (cf. with $\mathbf{A}$ and $\mathbf{B}$ ). The diagram on the left is non-weighted and does not consider the length of each mapped fault. The diagram on the right takes into account the linear distance between the northernmost and the southernmost point of each mapped fault, as an approximation of its length. Each fault segment is divided by the length of the smallest segment observed in the area, which is $\sim 0.5 \mathrm{~km}$. Both diagrams show a dominant NNE-SSE strike direction (see https://www.seismar.net/downloads/ for more information on the code used to extrapolate the faults strikes).

Figure 5. Blended TWT and variance maps of the top of (A) Units 5 (Muderong Shale), (B) 6 (Lower Gearle Siltstone), (C) 7 (Miria Marl), (D) an intra-Unit 8 reflection (calibrated to be Palaeocene in age, and named P, Dockrell Fm.), and (E) the top of Unit 8 (MidMiocene unconformity, within the Cape Range Group) (cf. with Figs. 2 and 3). The projected locations of the shallow and deep amplitude anomalies are shown in all the maps, as well as the locations of the stacked enhanced reflections observed in the SE sector of the study area between the Muderong Shale, and Miria Marl equivalents. The polygonal fault system is well imaged at the top of Unit 7 and within the Paleocene $(\mathbf{C}, \mathbf{D})$, but it extends up to the top of unit 8 (i.e. the Mid-Miocene unconformity) (E), where it is most visible in the NE side of the study area.

Figure 6. Seismic sections, showing possible evidence of a natural gas hydrate system. The location of the sections is shown in the inset map at bottom-left. The column on the right of each section indicates the boundaries of each stratigraphic unit. The BGHSZ is interpreted as the top of a series of enhanced 'soft' reflections (pink triangles). There is a BSR-like character in the examples shown here. The overlying amplitude anomalies could represent either gas hydrates or authigenic carbonates (grey triangles). A) Seismic section passing through Area I (see Tab. 2), which overlies the Brederode accumulation (blue arrows). Note the stacked enhanced 
reflections (ERs, yellow ellipse) around a fault offsetting the Cretaceous to Early Paleogene succession. B) Seismic section passing through the Area III (Tab. 2). C) Seismic section passing through the Area IV (see Tab. 2). In (B) and (C), note the area of seismic blanking and reflection distortion (black arrows) above the Upper Triassic succession. The arrows at the seafloor indicate depressions interpreted as pockmarks. Note the prominent rift-related extensional faults, as well as the polygonal fault system, both highlighted by black lines. MTD= mass-transport deposit. D, E, F) Blow-ups of selected portions of the seismic sections shown in $(\mathbf{A}),(\mathbf{B})$, and (C), respectively (red dashed rectangles), with wavelet extraction and superimposition of the modelled BGHSZs at bulk conditions (see text).

Figure 7. Composite seismic sections, showing different types of amplitude anomaly in the SE sector of the study area, including Areas VII (A, B) and IX (B), which include a bottom-simulating character. Both the sections pass through the Kentish Knock South accumulation (a dashed black line indicates the projection of the borehole Kentish Knock South-1). The blue arrows indicate the base of the Kentish Knock South accumulation (in this case a flat spot, which indicates the gas-water contact). Note also the stacked enhanced reflections (ERs), as well as the shallow anomalies, in both (A) and (B). The pink triangles indicate interpreted shallow free gas accumulations while the grey triangles indicate interpreted hydrate/authigenic carbonate accumulations. The ERs are distributed around a major extensional fault that offsets the Cretaceous succession above the Kentish Knock South accumulation. In (B), it is possible to see how the ERs also extend updip (as indicated by the yellow arrows), principally within Unit 5 (i.e. the Muderong Shale). MTD= mass-transport deposit.

Figure 8. Downhole temperature measurements at ODP Sites 762 and 763 (Leg 122, Swift et al., 1992) and industry wells (corrected bottom hole measurements, Esso Australia Ltd, 1980, 1981a, b, 1997; Phillips Australian Oil Company, 1980; BHP Billiton Petroleum Pty Ltd, 2005, 2006a, b, 2008, 2009; Chevron Australia Pty Ltd, 2010b, c, 2011b, 2013c, 2014; Woodside Energy Ltd, 2011, 2012). The purple arrow indicates the measurements at Sites 762 and 763, which indicate relatively high temperature at shallow depths at both sites. The Chevron well completion reports (Brederode-1, Arnhem-1, Kentish Knock-1, Guardian-1, and Kentish Knock South-1) provide a maximum, a minimum, and an intermediate formation temperature value, depending on the applied correction method. All these values are reported in the figure. The inset map at bottom-right indicates the location of the boreholes (762= ODP Site 762; 763= ODP Site 763; Ee= Eendracht-1; Br= Brederode-1; Ar= Arnhem-1; KK, G= Kentish Knock-1 and Guardian-1; KKS= Kentish Knock South-1; Th1,2= Thebe-1, 2; Ju= Jupiter-1; S1-5= Scarborough-1-5; Al= Alaric-1; Ca= Cadwallon-1; Vi= Vinck-1), as well as the perimeter of the Bonaventure 3D seismic survey.

Figure 9. Seismic sections, showing shallow amplitude anomalies, potentially indicating a natural gas hydrate system. The location of the sections is shown in the inset map at mid-right. These sections pass through Areas II (A), IV (B), V (C), and VI (D, E) (see Tab. 2 and Fig. 4B). The column on the right of each section indicates the boundaries of the stratigraphic units defined in this study. A BSR-like character is not observed in the examples shown here, and the pink triangles indicate shallow 'soft' anomalies interpreted as free gas. The grey triangles are 'hard anomalies' interpreted as either gas hydrates or authigenic carbonates. Area II is located above a fault block, west to the Arnhem accumulation. The blue arrows indicate amplitude anomalies within the Mungaroo Fm. (Unit 1), and interpreted as possible DHIs. The black dotted ellipse in (A) indicates a paleo-pockmark in the Late Triassic. The white arrows in (D) and (E) indicate a reflective top of Unit 1-base of Unit 2. The black arrows at the seafloor indicate depressions interpreted as pockmarks. Faults are highlighted by black lines. Note the presence of small-offset discontinuities associated with shallow amplitude anomalies in $(\mathbf{C}),(\mathbf{D})$, and $(\mathbf{E})$. ERs $=$ stacked enhanced reflections; MTD= mass-transport deposit.

Figure 10. A) RMS Amplitude extraction of the stratigraphic horizon marking the top of the Mungaroo Fm (Unit 1). Note that the amplitude of this horizon increases in the NW sector of the study area (white arrow). There is no drilling data in that area to constrain the origin of the amplitude increase (cf. with Fig. 6D, E). B) TWT isochore map of the stratigraphic interval comprised between the top of the Mungaroo Fm. (Unit 1), and the top of the Muderong Shale (Unit 5). Note how thickness decreases on the Late Triassic structural highs (cf. with Fig. 4A), particularly in the NW sector of the study area. The projected locations of the shallow amplitude anomalies, the DHIs in the Mungaroo Fm., and the stacked enhanced reflections observed in the SE sector of the study area between the Muderong Shale, and Miria Marl equivalents are shown in Both (A) and (B).

Figure 11. Geochemical data from ODP Site 762 (Leg 122, modified after Haq et al., 1990; De Carlo, 1992; Snowdon and Meyers, 1992) (A-E) and correlation with the Bonaventure 3D seismic survey (F), considering the stratigraphic units defined in this study (cf. with Fig. 2). The data includes porewater values of sulphate (A), chloride (B), total carbonate content of the sediment $(\mathbf{C})$, total organic carbon (TOC) (D), and headspace methane gas (E). The DHIs indicating the Eendracht accumulations are indicated by blue arrows in $(\mathbf{F})$.

Figure 12. Genetic diagrams (modified after Milkov, 2011) of natural gases showing the molecular and isotopic gas composition of the gas hosted within the Mungaroo Fm. in the study area. The plotted data is based on Modular Dynamic Formation Tester (MDT) 
analyses on gas samples recovered from boreholes Brederode-1, Arnhem-1, Kentish Knock-1, Guardian-1, Kentish Knock South-1, and Thebe-1 (BHP Billiton Petroleum Pty Ltd, 2008; Chevron Australia Pty Ltd, 2009, 2010b, 2011a, 2013a, b)

Figure 13. Schematic summaries of the interpreted hydrocarbon plumbing system, including a natural gas hydrate system, on the Exmouth Plateau. The cartoons are based on Figs. 6C and 7A. A) A hydrocarbon plumbing system where a deep source rock provides gas to a Late Triassic reservoir in the Mungaroo Fm. Leakage towards the GHSZ occurs via a cross-stratal advection process (through a fracture network?) from a gas reservoir at the crest of the footwall fault block. Free gas is trapped at the BGHSZ and may migrate updip along the three-phase boundary. Gas hydrates precipitate within the GHSZ. Where free gas is able to migrate to the seafloor, it leads to the formation of pockmarks. B) A case where free gas trapped within the Mungaroo Fm leaks into the shallower succession with a combination of cross-stratal advection through faults and stratal migration along preferential carrier beds. The shallowest free gas reservoir is the free gas zone. The semi-transparent red arrows indicate the possible gas migration direction. $\mathrm{SR}=$ source rock; FG RES. = free gas reservoir; FGZ= free gas zone; BGHSZ= base of the gas hydrate stability zone; GHBS= gas hydrate-bearing sediments; $\mathrm{MTD}=$ mass-transport deposit; $\mathrm{P}=$ pockmark; $\mathrm{TF}=$ tectonic fault; $\mathrm{PFS}=$ polygonal fault system. A simplified stratigraphic column is shown on the right of each cartoon.

\section{Table captions}

Table 1. Summary of the main characteristics of the areas of shallow hydrocarbon leakage (i.e. potentially related to a natural gas hydrate system) identified in the study area, in terms of seismic character and relation with deeper anomalies (see Fig. 4B for location).

Table 2. Summary resume of the main characteristics of gas accumulations identified in the study area, in terms of seismic character, petroleum system, and evidence of leakage (see Fig. 4B for location). The throw of the trap-bounding faults was measured at the top of the Mungaroo Fm. (Unit 1). Fault zones themselves could constitute additional seals for the gas accumulations. 


\section{References}

Alrefaee, H.A., Ghosh, S. \& Abdel-Fattah, M.I. 2018. 3D seismic characterization of the polygonal fault systems and its impact on fluid flow migration: An example from the Northern Carnarvon Basin, Australia. Journal of Petroleum Science and Engineering, 167, 120-130.

Anderson, R., Llamedo, M., Tohidi, B. \& Burgass, R.W. 2003. Experimental measurement of methane and carbon dioxide clathrate hydrate equilibria in mesoporous silica. The journal of physical chemistry $B, 107,3507-3514$.

Andreassen, K., Hubbard, A., Winsborrow, M., Patton, H., Vadakkepuliyambatta, S., PlazaFaverola, A., Gudlaugsson, E., Serov, P., Deryabin, A. \& Mattingsdal, R. 2017. Massive blow-out craters formed by hydrate-controlled methane expulsion from the Arctic seafloor. Science, 356, 948-953.

Andresen, K.J. 2012. Fluid flow features in hydrocarbon plumbing systems: What do they tell us about the basin evolution? Marine Geology, 332, 89-108.

Arntsen, B., Wensaas, L., Løseth, H. \& Hermanrud, C. 2007. Seismic modeling of gas chimneys. Geophysics, 72, SM251-SM259.

Baba, K. \& Yamada, Y. 2004. BSRs and associated reflections as an indicator of gas hydrate and free gas accumulation: An example of accretionary prism and forearc basin system along the Nankai Trough, off central Japan. Resource Geology, 54, 11-24.

Bailey, A.H.E., King, R.C., Holford, S.P. \& Hand, M. 2016a. Incompatible stress regimes from geological and geomechanical datasets: can they be reconciled? An example from the Carnarvon Basin, Western Australia. Tectonophysics, 683, 405-416.

Bailey, A.H.E., King, R.C., Holford, S.P. \& Hand, M. 2016b. Extending interpretations of natural fractures from the wellbore using 3D attributes: The Carnarvon Basin, Australia. Interpretation, 4, SB107-SB129.

Bailey, W.R., Underschultz, J., Dewhurst, D.N., Kovack, G., Mildren, S. \& Raven, M. 2006. Multidisciplinary approach to fault and top seal appraisal; Pyrenees-Macedon oil and gas fields, Exmouth Sub-basin, Australian Northwest Shelf. Marine and Petroleum Geology, 23, 241259.

Bhp Billiton Petroleum Pty Ltd 2005. Scarborough-3 and 3/CH1 well completion report, interpretive volume.

Bhp Billiton Petroleum Pty Ltd 2006a. Scarborough-5 well completion report, interpretive volume.

Bhp Billiton Petroleum Pty Ltd 2006b. Scarborough-4, 4A and 4/CH1 well completion report, interpretive volume.

Bhp Billiton Petroleum Pty Ltd 2008. Thebe-1 and Thebe-1CH well completion report, interpretive volume.

Bhp Billiton Petroleum Pty Ltd 2009. Thebe-2 and Thebe-2 CH well completion report, interpretive volume.

Bhp Billiton Petroleum Pty Ltd 2010. WA-42-L Macedon-10, Well completion report, Interpretive data, Volume 3.

Black, M., Mccormack, K.D., Elders, C. \& Robertson, D. 2017. Extensional fault evolution within the Exmouth Sub-basin, North West Shelf, Australia. Marine and Petroleum Geology, 85, 301-315.

Borowski, W.S. 2004. A review of methane and gas hydrates in the dynamic, stratified system of the Blake Ridge region, offshore southeastern North America. Chemical Geology, 205, 311346.

Boswell, R., Shipp, C., Reichel, T., Shelander, D., Saeki, T., Frye, M., Shedd, W., Collett, T.S. \& Mcconnell, D.R. 2016. Prospecting for marine gas hydrate resources. Interpretation, 4, SA13-SA24.

Boyd, R., Williamson, P. \& Haq, B. 1993. Seismic Stratigraphy and Passive- Margin Evolution of the Southern Exmouth Plateau. Sequence Stratigraphy and Facies Associations, 579-603. 
Bünz, S., Polyanov, S., Vadakkepuliyambatta, S., Consolaro, C. \& Mienert, J. 2012. Active gas venting through hydrate-bearing sediments on the Vestnesa Ridge, offshore W-Svalbard. Marine Geology, 332, 189-197.

Cartwright, J.A. \& Lonergan, L. 1996. Volumetric contraction during the compaction of mudrocks: A mechanism for the development of regional- scale polygonal fault systems. Basin Research, 8, 183-193.

Cartwright, J.A. \& Dewhurst, D.N. 1998. Layer-bound compaction faults in fine-grained sediments. Geological Society of America Bulletin, 110, 1242-1257.

Cartwright, J.A., Huuse, M. \& Aplin, A. 2007. Seal bypass systems. AAPG Bulletin, 91, 1141-1166.

Cartwright, J.A. \& Santamarina, C. 2015. Seismic characteristics of fluid escape pipes in sedimentary basins: implications for pipe genesis. Marine and Petroleum Geology, 65, 126140.

Chen, D.F. \& Cathles, L.M. 2003. A kinetic model for the pattern and amounts of hydrate precipitated from a gas steam: Application to the Bush Hill vent site, Green Canyon Block 185, Gulf of Mexico. Journal of Geophysical Research: Solid Earth, 108, B1, 2058.

Chevron Australia Pty Ltd 2009. Guardian 1, Well Completion Report - Basic Data, Exmouth Plateau: WA-365-P.

Chevron Australia Pty Ltd 2010a. Kentish Knock 1, Well Completion Report - Basic Data, Exmouth Plateau: WA-365-P.

Chevron Australia Pty Ltd 2010b. Kentish Knock 1, Carnarvon Basin: WA-365-P, Well Completion Report (Interpretive Data).

Chevron Australia Pty Ltd 2010c. Guardian 1, Carnarvon Basin: WA-365-P, Well Completion Report (Interpretive Data).

Chevron Australia Pty Ltd 2011a. Brederode 1, Well Completion Report - Basic Data, Carnarvon Basin: WA-364P-R1.

Chevron Australia Pty Ltd 2011b. Brederode 1, Carnarvon Basin: WA-364-P (R1), Well Completion Report (Interpretive Data).

Chevron Australia Pty Ltd 2013a. Arnhem 1, Initial Well Completion Report, Carnarvon Basin: WA-364-P (R1).

Chevron Australia Pty Ltd 2013b. Arnhem 1, Final Well Completion Report, Carnarvon Basin: WA-364-P (R1).

Chevron Australia Pty Ltd 2013c. Kentish Knock South 1, Initial Well Completion Report, Carnarvon Basin: WA-365-P (R1).

Chevron Australia Pty Ltd 2014. Kentish Knock South 1, Final Well Completion Report, Carnarvon Basin: WA-365-P (R1).

Chongzhi, T., Guoping, B., Junlan, L., Chao, D., Xiaoxin, L., Houwu, L., Dapeng, W., Yuan, W. \& Min, L. 2013. Mesozoic lithofacies palaeogeography and petroleum prospectivity in North Carnarvon Basin, Australia. Journal of Palaeogeography, 2, 81-92.

Clennell, M.B., Hovland, M., Booth, J.S., Henry, P. \& Winters, W.J. 1999. Formation of natural gas hydrates in marine sediments: 1 . Conceptual model of gas hydrate growth conditioned by host sediment properties. Journal of Geophysical Research: Solid Earth, 104, 22985-23003.

Clennell, M.B., Judd, A. \& Hovland, M. 2000. Movement and accumulation of methane in marine sediments: relation to gas hydrate systems. In: Max, M.D. (ed.) Natural Gas Hydrate in oceanic and permafrost environments, 105-122. Springer.

Collett, T.S., Johnson, A.H., Knapp, C.C. \& Boswell, R. 2009. Natural gas hydrates: a review. In: Collett, T.S., Knapp, C.C. \& Boswell, R. (eds.) Natural gas hydrates-Energy Resource Potential and Associated Geologic Hazards. AAPG Memoir, 89, 146-219.

Collett, T.S., Lee, M.W., Agena, W.F., Miller, J.J., Lewis, K.A., Zyrianova, M.V., Boswell, R. \& Inks, T.L. 2011. Permafrost-associated natural gas hydrate occurrences on the Alaska North Slope. Marine and Petroleum Geology, 28, 279-294. 
Cook, A.C., Smyth, M. \& Vos, R.G. 1985. Source potential of Upper Triassic fluvio-deltaic systems of the Exmouth Plateau. The APPEA Journal, 25, 204-215.

Cook, A.E., Goldberg, D. \& Kleinberg, R.L. 2008. Fracture-controlled gas hydrate systems in the northern Gulf of Mexico. Marine and Petroleum Geology, 25, 932-941.

Cook, A.E., Goldberg, D.S. \& Malinverno, A. 2014. Natural gas hydrates occupying fractures: A focus on non-vent sites on the Indian continental margin and the northern Gulf of Mexico. Marine and Petroleum Geology, 58, 278-291.

Cowley, R. \& O'brien, G.W. 2000. Identification and interpretation of leaking hydrocarbons using seismic data: A comparative montage of examples from the major fields in Australia's northwest shelf and Gippsland basin. The APPEA Journal, 40, 119-150.

Crutchley, G.J., Berndt, C., Geiger, S., Klaeschen, D., Papenberg, C., Klaucke, I., Hornbach, M.J., Bangs, N.L. \& Maier, C. 2013. Drivers of focused fluid flow and methane seepage at south Hydrate Ridge, offshore Oregon, USA. Geology, 41, 551-554.

Crutchley, G.J., Klaeschen, D., Planert, L., Bialas, J., Berndt, C., Papenberg, C., Hensen, C., Hornbach, M., Krastel, S. \& Brückmann, W. 2014. The impact of fluid advection on gas hydrate stability: Investigations at sites of methane seepage offshore Costa Rica. Earth and Planetary Science Letters, 401, 95-109.

De Carlo, E.H. 1992 Geochemistry of pore water and sediments recovered from the Exmouth Plateau. In: von Rad, U., Haq, B.U. \& al., e., eds. Proc. Ocean Drill. Program.

De Mol, B., Van Rensbergen, P., Pillen, S., Van Herreweghe, K., Van Rooij, D., McDonnell, A., Huvenne, V., Ivanov, M., Swennen, R. \& Henriet, J.P., 2002. Large deep-water coral banks in the Porcupine Basin, southwest of Ireland. Marine Geology, 188, 93-231.

De Prunelé, A., Ruffine, L., Riboulot, V., Peters, C.A., Croguennec, C., Guyader, V., Pape, T., Bollinger, C., Bayon, G. \& Caprais, J.C. 2017. Focused hydrocarbon- migration in shallow sediments of a pockmark cluster in the Niger Delta (Off Nigeria). Geochemistry, Geophysics, Geosystems, 18, 93-112.

Dewhurst, D.N., Jones, R.M. \& Raven, M.D. 2002. Microstructural and petrophysical characterization of Muderong Shale: application to top seal risking. Petroleum Geoscience, 8, 371-383.

Dewhurst, D.N. \& Hennig, A.L. 2003. Geomechanical properties related to top seal leakage in the Carnarvon Basin, Northwest Shelf, Australia. Petroleum Geoscience, 9, 255-263.

Dirstein, J.K., Hengesh, J.V. \& Stanley, A.J. 2013 Identification of Fluid Flow Features in the Seafloor and Subsurface and their Implications for Prospect and Geohazard Assessment: Examples from the Australian Northwest Shelf. Western Australian Basin Symposium (WABS), Perth, WA.

Downey, M.W. 1984. Evaluating seals for hydrocarbon accumulations. AAPG Bulletin, 68, 17521763.

Esso Australia Ltd 1980. Well Completion Report Scarborough-1. Data Repository, Australian Government, Geoscience Australia.

Esso Australia Ltd 1981a. Well Completion Report Vinck-1. Data Repository, Australian Government, Geoscience Australia.

Esso Australia Ltd 1981b. Well Completion Report Eendracht-1. Data Repository, Australian Government, Geoscience Australia.

Esso Australia Ltd 1997. Well Completion Report Scarborough-2. Data Repository, Australian Government, Geoscience Australia.

Etiope, G., Lassey, K.R., Klusman, R.W. \& Boschi, E. 2008a. Reappraisal of the fossil methane budget and related emission from geologic sources. Geophysical Research Letters, 35.

Etiope, G., Milkov, A.V. \& Derbyshire, E. 2008b. Did geologic emissions of methane play any role in Quaternary climate change? Global and Planetary Change, 61, 79-88. 
Exon, N.F. \& Willcox, J.B. 1980. The Exmouth Plateau--stratigraphy, structure, and petroleum potential. National Gallery of Australia.

Exon, N.F. \& Buffler, R.T. 1992 Mesozoic seismic stratigraphy and tectonic evolution of the western Exmouth Plateau. Proceedings of the Ocean Drilling Program, Scientific Results, Vol. 122.

Exon, N.F., Haq, B.U. \& Von Rad, U. 1992 Exmouth Plateau revisited: scientific drilling and geological framework. Proceedings of the Ocean Drilling Program, Scientific Results, Vol. 122.

Eyles, C.H., Mory, A.J. \& Eyles, N. 2003. Carboniferous-Permian facies and tectono-stratigraphic successions of the glacially influenced and rifted Carnarvon Basin, Western Australia. Sedimentary Geology, 155, 63-86.

Feary, D.A., \& James, N.P. 1995. Cenozoic biogenic mounds and buried Miocene (?) barrier reef on a predominantly cool-water carbonate continental margin-Eucla basin, western Great Australian Bight. Geology, 23, 427-430.

Foschi, M., Cartwright, J.A. \& Peel, F.J. 2014. Vertical anomaly clusters: Evidence for vertical gas migration across multilayered sealing sequences. AAPG Bulletin, 98, 1859-1884.

Foschi, M., Cartwright, J.A. \& Macminn, C.W. 2017. Sequential vertical gas charge into multilayered sequences controlled by central conduits. AAPG Bulletin.

Fossen, H. \& Rotevatn, A. 2016. Fault linkage and relay structures in extensional settings-A review. Earth-Science Reviews, 154, 14-28.

Fujii, T., Suzuki, K., Takayama, T., Tamaki, M., Komatsu, Y., Konno, Y., Yoneda, J., Yamamoto, K. \& Nagao, J., 2015. Geological setting and characterization of a methane hydrate reservoir distributed at the first offshore production test site on the Daini-Atsumi Knoll in the eastern Nankai Trough, Japan. Marine and Petroleum Geology, 66, 310-322.

Gartrell, A., Zhang, Y., Lisk, M. \& Dewhurst, D. 2004. Fault intersections as critical hydrocarbon leakage zones: integrated field study and numerical modelling of an example from the Timor Sea, Australia. Marine and Petroleum Geology, 21, 1165-1179.

Gartrell, A., Torres, J., Dixon, M. \& Keep, M. 2016. Mesozoic rift onset and its impact on the sequence stratigraphic architecture of the Northern Carnarvon Basin. The APPEA Journal, 56, 143-158.

Gartrell, A.P. 2000. Rheological controls on extensional styles and the structural evolution of the Northern Carnarvon Basin, North West Shelf, Australia. Australian Journal of Earth Sciences, 47, 231-244.

Geoscience Australia 2012. Petroleum Geological Summary, Release Areas W12-10, W12-11, W12-12, W12-13 AND W12-14 Exmouth Plateau, Northern Carnarvon Basin, Western Australia. Australia 2012, Offshore Petroleum Exploration Acreage Release. Australian Government, Department of Resources, Energy and Tourism.

Geoscience Australia 2014. Regional Geology of the Northern Carnarvon Basin, Offshore Petroleum Exploration Acreage Release, Australia 2014. Australian Government, Department of Industry.

Goktas, P., Austin Jr, J.A., Fulthorpe, C.S., \& Gallagher, S.J. 2016. Morphologies and depositional/erosional controls on evolution of Pliocene-Pleistocene carbonate platforms: Northern Carnarvon Basin, Northwest Shelf of Australia. Continental Shelf Research, 124, 63-82.

Gorman, A.R., Holbrook, W.S., Hornbach, M.J., Hackwith, K.L., Lizarralde, D. \& Pecher, I.A. 2002. Migration of methane gas through the hydrate stability zone in a low-flux hydrate province. Geology, 30, 327-330.

Haq, B.U., Von Rad, U. \& Party, S.S. 1990. Proceedings of the Ocean Drlling Project, Initial Reports, Vol. 122. 
Haq, B.U., Boyd, R.L., Exon, N.F. \& Von Rad, U. 1992. Evolution of the central exmouth plateau: a post-drilling perspective. Proceedings of the Ocean Drilling Project, Scientific Results, Vol. 122.

Hengesh, J.V., Whitney, B.B. \& Rovere, A. 2011 A Tectonic Influence On Seafloor Stability Along Australia's North West Shelf. The Twenty-first International Offshore and Polar Engineering Conference.

Henry, P., Thomas, M. \& Clennell, M.B. 1999. Formation of natural gas hydrates in marine sediments, 2, Thermodynamic calculations of stability conditions in porous sediments. Journal of Geophysical Research, 104, 23005-23022.

Hermanrud, C., Venstad, J.M., Cartwright, J.A., Rennan, L., Hermanrud, K. \& Bolås, H.M.N. 2013. Consequences of water level drops for soft sediment deformation and vertical fluid leakage. Mathematical Geosciences, 45, 1-30.

Hermanrud, C., Halkjelsvik, M.E., Kristiansen, K., Bernal, A. \& Strömbäck, A.C. 2014. Petroleum column-height controls in the western Hammerfest Basin, Barents Sea.

Hillis, R.R., Sandiford, M., Reynolds, S.D. \& Quigley, M.C. 2008. Present-day stresses, seismicity and Neogene-to-Recent tectonics of Australia's 'passive'margins: intraplate deformation controlled by plate boundary forces. Geological Society, London, Special Publications, 306, 71-90.

Hillman, J.I.T., Cook, A.E., Sawyer, D.E., Küçük, H.M. \& Goldberg, D.S. 2017. The character and amplitude of 'discontinuous' bottom-simulating reflections in marine seismic data. Earth and Planetary Science Letters, 459, 157-169.

Holbrook, W.S., Hoskins, H., Wood, W.T., Stephen, R.A. \& Lizarralde, D. 1996. Methane hydrate and free gas on the Blake Ridge from vertical seismic profiling. Science, 273, 1840.

Hovland, M., Croker, P.F. \& Martin, M. 1994. Fault-associated seabed mounds (carbonate knolls?) off western Ireland and north-west Australia. Marine and Petroleum Geology, 11, 232-246.

Hustoft, S., Mienert, J., Bünz, S. \& Nouzé, H. 2007. High-resolution 3D-seismic data indicate focussed fluid migration pathways above polygonal fault systems of the mid-Norwegian margin. Marine Geology, 245, 89-106.

Imbert, P., \& Ho, S. 2012. Seismic-scale funnel-shaped collapse features from the PaleoceneEocene of the North West Shelf of Australia. Marine Geology, 332, 198-221.

Jablonski, D., Preston, J., Westlake, S. \& Gumley, C.M. 2013. Unlocking the Origin of Hydrocarbons in the Central Part of the Rankin Trend, Northern Carnarvon Basin, Australia. West Australian Basins Symposium, 2013. Perth, WA.

Jones, R.M. \& Hillis, R.R. 2003. An integrated, quantitative approach to assessing fault-seal risk. AAPG Bulletin, 87, 507-524.

Judd, A.G. \& Hovland, M. 2007. Seabed Fluid Flow: The Impact on Geology, Biology and the Marine Environment, Cambridge University Press.

Karner, G.D. \& Driscoll, N.W. 1999. Style, timing and distribution of tectonic deformation across the Exmouth Plateau, northwest Australia, determined from stratal architecture and quantitative basin modelling. Geological Society, London, Special Publications, 164, 271311.

Laird, A.P. \& Morley, C.K. 2011. Development of gas hydrates in a deep-water anticline based on attribute analysis from three-dimensional seismic data. Geosphere, 7, 240-259.

Langhi, L., Zhang, Y., Gartrell, A., Underschultz, J. \& Dewhurst, D. 2010. Evaluating hydrocarbon trap integrity during fault reactivation using geomechanical three-dimensional modeling: An example from the Timor Sea, Australia. AAPG Bulletin, 94, 567-591.

Leather, D.T., Bahadori, A., Nwaoha, C. \& Wood, D.A. 2013. A review of Australia's natural gas resources and their exploitation. Journal of Natural Gas Science and Engineering, 10, 6888. 
Lee, M.W. 2004. Elastic velocities of partially gas-saturated unconsolidated sediments. Marine and Petroleum Geology, 21, 641-650.

Li, A., Davies, R.J., Mathias, S.A., Yang, J., Hobbs, R. \& Wilson, M. 2017. Gas venting that bypasses the feather edge of marine hydrate, offshore Mauritania. Marine and Petroleum Geology, 88, 402-409.

Li, C., Hu, G., Zhang, W., Ye, Y., Liu, C., Li, Q. \& Sun, J. 2016. Influence of foraminifera on formation and occurrence characteristics of natural gas hydrates in fine-grained sediments from Shenhu area, South China Sea. Science China Earth Sciences, 59, 2223-2230.

Longley, I., Buessenschuett, C., Clydsdale, L., Cubitt, C., Davis, R., Johnson, M., Marshall, N., Murray, A., Somerville, R. \& Spry, T. 2002 The North West Shelf of Australia-a Woodside perspective. The Sedimentary Basins of Western Australia 3: Proceedings of the Petroleum Exploration Society of Australia Symposium, Perth.

Løseth, H., Gading, M. \& Wensaas, L. 2009. Hydrocarbon leakage interpreted on seismic data. Marine and Petroleum Geology, 26, 1304-1319.

Malinverno, A. \& Goldberg, D.S. 2015. Testing short-range migration of microbial methane as a hydrate formation mechanism: Results from Andaman Sea and Kumano Basin drill sites and global implications. Earth and Planetary Science Letters, 422, 105-114.

Marsset, T., Ruffine, L., Gay, A., Ker, S. \& Cauquil, E. 2018. Types of fluid-related features controlled by sedimentary cycles and fault network in deepwater Nigeria. Marine and Petroleum Geology, 89, 330-349.

Matsumoto, R., Tanahashi, M., Kakuwa, Y., Snyder, G., Ohkawa, S., Tomaru, H. \& Morita, S., 2017. Recovery of thick deposits of massive gas hydrates from gas chimney structures, eastern margin of Japan Sea: Japan Sea Shallow Gas Hydrate Project. Fire in the Ice, 17, 16.

Meyers, P.A. \& Snowdon, L.R. 1993. Sources and migration of methane-rich gas in sedimentary rocks on the Exmouth Plateau: Northwest Australian continental margin. Biogeochemistry of global change. Springer.

Milkov, A.V. 2005. Molecular and stable isotope compositions of natural gas hydrates: a revised global dataset and basic interpretations in the context of geological settings. Organic Geochemistry, 36, 681-702.

Milkov, A.V. 2011. Worldwide distribution and significance of secondary microbial methane formed during petroleum biodegradation in conventional reservoirs. Organic Geochemistry, 42, 184-207.

Müller, P.J. \& Suess, E. 1979. Productivity, sedimentation rate, and sedimentary organic matter in the oceans-I. Organic carbon preservation. Deep Sea Research Part A. Oceanographic Research Papers, 26, 1347-1362.

Müller, R.D., Dyksterhuis, S. \& Rey, P. 2012. Australian paleo-stress fields and tectonic reactivation over the past $100 \mathrm{Ma}$. Australian Journal of Earth Sciences, 59, 13-28.

Ostanin, I., Anka, Z., Di Primio, R. \& Bernal, A. 2013. Hydrocarbon plumbing systems above the Snøhvit gas field: structural control and implications for thermogenic methane leakage in the Hammerfest Basin, SW Barents Sea. Marine and Petroleum Geology, 43, 127-146.

Paganoni, M., Cartwright, J.A., Foschi, M., Shipp, C.R. \& Van Rensbergen, P. 2018. Relationship between fluid-escape pipes and hydrate distribution in offshore Sabah (NW Borneo). Marine Geology, 395, 82-103.

Paull, C.K., Normark, W.R., Ussler, W., Caress, D.W. \& Keaten, R. 2008a. Association among active seafloor deformation, mound formation, and gas hydrate growth and accumulation within the seafloor of the Santa Monica Basin, offshore California. Marine Geology, 250, 258-275.

Paull, C.K., Ussler Iii, W., Holbrook, W.S., Hill, T.M., Keaten, R., Mienert, J., Haflidason, H., Johnson, J.E., Winters, W.J. \& Lorenson, T.D. 2008b. Origin of pockmarks and chimney 
structures on the flanks of the Storegga Slide, offshore Norway. Geo-Marine Letters, 28, 4351.

Pecher, I.A., Henrys, S.A., Wood, W.T., Kukowski, N., Crutchley, G.J., Fohrmann, M., Kilner, J., Senger, K., Gorman, A.R. \& Coffin, R.B. 2010. Focussed fluid flow on the Hikurangi Margin, New Zealand-Evidence from possible local upwarping of the base of gas hydrate stability. Marine Geology, 272, 99-113.

Phillips Australian Oil Company 1980. Well completion report, Jupiter No. 1 well.

Plaza-Faverola, A., Bünz, S., \& Mienert, J. 2011. Repeated fluid expulsion through sub-seabed chimneys offshore Norway in response to glacial cycles. Earth and Planetary Science Letters, 305, 297-308.

Rebesco, M., Hernández-Molina, F.J., Van Rooij, D. \& Wåhlin, A. 2014. Contourites and associated sediments controlled by deep-water circulation processes: state-of-the-art and future considerations. Marine Geology, 352, 111-154.

Riboulot, V., Sultan, N., Imbert, P. \& Ker, S. 2016. Initiation of gas-hydrate pockmark in deepwater Nigeria: Geo-mechanical analysis and modelling. Earth and Planetary Science Letters, 434, 252-263.

Roberts, J.M., Wheeler, A.J. \& Freiwald, A., 2006a. Reefs of the deep: the biology and geology of cold-water coral ecosystems. Science, 312, 543-547.

Roberts, H.H., Hardage, B.A., Shedd, W.W., \& Hunt Jr, J., 2006b. Seafloor reflectivity-An important seismic property for interpreting fluid/gas expulsion geology and the presence of gas hydrate. The Leading Edge, 25, 620-628.

Ryan, G.J., Bernardel, G., Kennard, J.M., Jones, A.T., Logan, G.N. \& Rollet, N. 2009. A precursor extensive Miocene reef system to the Rowley Shoals reefs, Western Australia: Evidence for structural control of reef growth or natural hydrocarbon seepage? The APPEA Journal, 49, 337-363.

Sassen, R., Joye, S., Sweet, S.T., Defreitas, D.A., Milkov, A.V. \& Macdonald, I.R. 1999. Thermogenic gas hydrates and hydrocarbon gases in complex chemosynthetic communities, Gulf of Mexico continental slope. Organic Geochemistry, 30, 485-497.

Sassen, R., Losh, S., Cathles, L., Roberts, H., Whelan, J., Milkov, A., Sweet, S. \& Defreitas, D. 2001. Massive vein-filling gas hydrate: relation to ongoing gas migration from the deep subsurface in the Gulf of Mexico. Marine and Petroleum Geology, 18, 551-560.

Scarselli, N., Mcclay, K. \& Elders, C. 2013 Submarine slide and slump complexes, Exmouth Plateau, NW shelf of Australia. The Sedimentary Basins of Western Australia IV: Proceedings of the Petroleum Exploration Society of Australia Symposium. Perth, WA.

Serié, C., Huuse, M. \& Schødt, N.H. 2012. Gas hydrate pingoes: Deep seafloor evidence of focused fluid flow on continental margins. Geology, 40, 207-210.

Shedd, W., Boswell, R., Frye, M., Godfriaux, P. \& Kramer, K. 2012. Occurrence and nature of "bottom simulating reflectors" in the northern Gulf of Mexico. Marine and Petroleum Geology, 34, 31-40.

Simonetti, A., Knapp, J.H., Sleeper, K., Lutken, C.B., Macelloni, L. \& Knapp, C.C. 2013. Spatial distribution of gas hydrates from high-resolution seismic and core data, Woolsey Mound, Northern Gulf of Mexico. Marine and Petroleum Geology, 44, 21-33.

Sloan Jr, E.D. \& Koh, C. 2007. Clathrate hydrates of natural gases, CRC press.

Smith, A.J., Mienert, J., Bünz, S. \& Greinert, J. 2014. Thermogenic methane injection via bubble transport into the upper Arctic Ocean from the hydrate- charged Vestnesa Ridge, Svalbard. Geochemistry, Geophysics, Geosystems, 15, 1945-1959.

Snowdon, L.R. \& Meyers, P.A. 1992 Source and maturity of organic matter in sediments and rocks from Sites 759, 760, 761, and 764 (Wombat Plateau) and Sites 762 and 763 (Exmouth Plateau). Proceedings of the Ocean Drilling Program, Scientific Results, Vol. 122. 
Spencer, A.M. \& Larsen, V.B. 1990. Fault traps in the northern North Sea. Geological Society, London, Special Publications, 55, 281-298.

Stranne, C., \& O'Regan, M. 2016. Conductive heat flow and nonlinear geothermal gradients in marine sediments - observations from Ocean Drilling Program boreholes. Geo-Marine Letters, 36, 25-33.

Swift, M., Boyd, R., O'brien, D. \& Lorenzo, J. 1992 Heat flow and thermal history of the Exmouth Plateau. von Rad, U., Haq, B. U., et al., 1992, Proceedings of the Ocean Drilling Program, Scientific Results, Vol. 122.

Taylor, M.H., Dillon, W.P. \& Pecher, I.A. 2000. Trapping and migration of methane associated with the gas hydrate stability zone at the Blake Ridge Diapir: new insights from seismic data. Marine Geology, 164, 79-89.

Tindale, K., Newell, N., Keall, J. \& Smith, N. 1998 Structural evolution and charge history of the Exmouth Sub-basin, northern Carnarvon Basin, Western Australia. The Sedimentary Basins of Western Australia 2: Proceedings of the Petroleum Exploration Society of Australia Symposium, Perth.

Tingay, M.R.P., Hillis, R.R., Swarbrick, R.E., Morley, C.K. \& Damit, A.R. 2007. 'Vertically transferred'overpressures in Brunei: Evidence for a new mechanism for the formation of high-magnitude overpressure. Geology, 35, 1023-1026.

Tréhu, A.M., Torres, M.E., Bohrmann, G. \& Colwell, F. 2006 1. Leg 204 synthesis: Gas hydrate distribution and dynamics in the central Cascadia accretionary complex. Proceedings of the Ocean Drilling Program, Scientific Results, Vol. 204.

Uchida, T., Ebinuma, T., Takeya, S., Nagao, J. \& Narita, H. 2002. Effects of pore sizes on dissociation temperatures and pressures of methane, carbon dioxide, and propane hydrates in porous media. The journal of physical chemistry B, 106, 820-826.

Underschultz, J.R. 2007. Hydrodynamics and membrane seal capacity. Geofluids, 7, 148-158.

Velayatham, T., Holford, S.P. \& Bunch, M.A. 2018. Ancient fluid flow recorded by remarkably long, buried pockmark trains observed in 3D seismic data, Exmouth Plateau, Northern Carnarvon Basin. Marine and Petroleum Geology.

Volkman, J.K., Alexander, R., Kagi, R.I., Noble, R.A. \& Woodhouse, C.W. 1983. A geochemical reconstruction of oil generation in the Barrow Sub-basin of Western Australia. Geochimica et Cosmochimica Acta, 47, 2091-2105.

Wallmann, K., Aloisi, G., Haeckel, M., Obzhirov, A., Pavlova, G. \& Tishchenko, P. 2006. Kinetics of organic matter degradation, microbial methane generation, and gas hydrate formation in anoxic marine sediments. Geochimica et Cosmochimica Acta, 70, 3905-3927.

Watts, N.L. 1987. Theoretical aspects of cap-rock and fault seals for single-and two-phase hydrocarbon columns. Marine and Petroleum Geology, 4, 274-307.

Williams, R.M. 2018. Derisking the Thebe Discovery through cognitive interpretation. First Break, $36,71-78$.

Wiprut, D. \& Zoback, M.D. 2000. Fault reactivation and fluid flow along a previously dormant normal fault in the northern North Sea. Geology, 28, 595-598.

Woodside Energy Ltd 2011. Alaric-1 Final Well Completion Report.

Woodside Energy Ltd 2012. Cadwallon-1 Final Well Completion Report.

Yardley, G. \& Swarbrick, R. 2000. Lateral transfer: A source of additional overpressure? Marine and Petroleum Geology, 17, 523-537. 